\title{
Rallying the Troops and Defending against Sanctions: A Government Body Breaking Decision- Making Rules to Fund Entrepreneurial Ventures
}

\author{
DEAN A. SHEPHERD \\ Mendoza College of Business \\ University of Notre Dame \\ Notre Dame, IN \\ dshepherd@nd.edu \\ JEANETH JOHANSSON \\ Luleå University of Technology \\ Entrepreneurship \& Innovation \\ Luleå, Sweden \\ and \\ Halmstad University \\ School of Business, Engineering and Science \\ Halmstad, Sweden \\ jeaneth.johansson@1tu.se \\ Phone: 46920492364 \\ MALIN MALMSTRÖM \\ Luleå University of Technology \\ Entrepreneurship \& Innovation \\ Luleå, Sweden \\ Malin.malmstrom@1tu.se \\ Phone: 46920491087 \\ JOAKIM WINCENT \\ Hanken School of Economics \\ FI-00101 Helsinki, Finland \\ Tel.: +358 403521 478; E-mail: joakim.wincent@hanken.fi
}

This article has been accepted for publication and undergone full peer review but has not been through the copyediting, typesetting, pagination and proofreading process, which may lead to differences between this version and the Version of Record. Please cite this article as doi:

10.1111/JOMS.12562

This article is protected by copyright. All rights reserved 
University of St.Gallen; Global Center Entrepreneurship and Innovation; Institute of Technology Management Dufourstrasse 40, CH-9000 St. Gallen, Switzerland

This article is protected by copyright. All rights reserved 


\section{ABSTRACT}

Critical to top management's organizing efforts are the formal rules for how organizational members are to make decisions. However, employees can break top management's decision-making rules. Although scholars have investigated rule breaking at the individual and group levels of analysis, research is needed into how members come together as a group to break an organization's decisionmaking rules, and how groups' rule breaking persists. To address this important research gap, we draw from a real-time qualitative investigation of both the breaking and following of decision-making rules to develop a group model that: (1) explains how an individual can trigger his or her group to break decision-making rules to generate perceived benefits for the group and/or others external to the organization, (2) provides insights into the mechanisms by which rule breaking persists, and (3) highlights the norms of developing and perpetuating groups' breaking decision-making rules.

Keywords: Decision making, Entrepreneurial funding, Government, Groups, Rule breaking 


\section{INTRODUCTION}

\section{"Learn the rules like a pro, so you can break them like an artist." Pablo Picasso}

Since the advent of the modern organization, managers have emphasized the importance of organizational members" adherence to formal rules for "successful coordination and functioning within organizations" (Tyler and Blader, 2005, p. 1143). Rules are "formalized prescriptions and proscriptions about appropriate actions" (Lehman and Ramanujam, 2009, p. 644) and, in the organizational context, are formalized by top management with the expectation that they help organize employees in a way that enhances coordination, efficiency, and performance (like Martin et al. [2013], we focus only on formal rules). Of particular importance to top management in their organizing efforts are the formal rules for how organizational members are to make decisions (Simon, 1947; Gavetti, Levinthal, and Ocasio, 2007), such as decisions about how to execute a process, about which potential opportunities to pursue (and which not to pursue), about which actions to prioritize, and about when to exit (Bingham and Eisenhardt, 2011; Eisenhardt and Sull, 2001; McGrath, 1999). However, despite the potential of sanctions (Hale and Borys, 2013; Morrison, 2006), employees can break top management's decision-making rules, sometimes to benefit themselves as the rule breaker at the expense of their organization (e.g., Sims, 2002) and sometimes to benefit someone else (e.g., a dissatisfied customer) for organizational benefit (e.g., Vardaman, Gondo, and Allen, 2014). We refer to group decision making as the selection of one alternative from a set of alternatives (Davis, Laughlin and Komorita, 1976), and the rules for this group decision making control how the group deliberates and determines the alternative selected (Tindale and Winget, 2019).

Although rule breaking has been studied at the individual (Colbert et al., 2004; Judge, Scott, and Ilies, 2006) and group (Adler and Borys, 1996; Sallaz, 2009) levels of analysis, research has suggested that further clarifying how members come to break group decision-making rules could help strengthen our understanding of a breakdown in top management's formal organizing efforts (Desai, 2010). ${ }^{1}$ Rule breaking refers to an "intentional violation of an explicit organizationally defined policy, regulation, or prohibition" (Morrison, 2006, p. 6) and "becomes a group-level activity when it is undertaken in an organized way in pursuit of group-level goals and members of the group expect or require other members to participate" (Martin et al., 2013, p. 561). Building on the above (i.e., Davis 
et al., 1976; Morrison, 2006; Tindale and Winget, 2019), we define the breaking of a group decisionmaking rule as the intentional violation of an explicit formal policy, regulation, or prohibition from top management for how groups within the organization are to deliberate and determine the selection one alternative from a set of alternatives. For example, it appears that the Houston Astros baseball team broke rules:

"Stealing pitching signs is as old as modern baseball, which by some accounts precedes the Civil War. It's rarely penalized, however, because virtually every team tries to figure out what the opposing catcher is signaling his pitcher to throw and relay that information to batters. What has gotten the Astros in hot water is their alleged method of stealing signs - with video cameras, which is explicitly prohibited by MLB. Former Astros pitcher Mike Fiers has accused the team of using a center-field camera at Minute Maid Park to steal opposing catchers' signs and bang a dugout trash can to alert batters if an off-speed pitch is expected. No bang? Look for a fastball” (Editorial Board, Houston Chronicle, 11-20-2019).

When considering the group process of rule breaking, identifying the mechanisms that connect individuals becomes important (Vaughan, 1990). Therefore, in this study, we ask the following: how do members come together as a group to break an organization's decision-making rules, and how does this group rule breaking persist? To address these research questions, we draw from a real-time qualitative investigation (consistent with the Gioia, Corley, and Hamilton, 2013) of both the breaking and following of decision-making rules within the context of 169 group decisions by groups within a government department deciding on entrepreneurs' funding applications (i.e., the unit of analysis is the 169 group decisions). Our group model of breaking decision-making rules makes three primary contributions to the literature on rule breaking.

First, with this study, we contribute to the literature on rule breaking by either individual employees (Dahling et al., 2012; Giacalone and Greenberg, 1997; Vardi and Weitz, 2004) or workgroups (Martin et al., 2013; Sallaz, 2002, 2009), a decision-making perspective in which individual members rally as a group to break top management's rules. In this context, rallying refers to the process of individuals coming together to form a group to break a decision-making rule. Specifically, the rule-breaking literature has not sufficiently explored how individuals become a group 
to break group decision-making rules. In this study, we explain how an individual can trigger his or her group to break decision-making rules to generate perceived benefits for the group and/or others external to the organization.

Second, we know that despite top management's expectations for rule following and sanctions for those who do not follow the rules (Morrison, 2006; Tyler and Blader, 2005), rule breaking is prevalent in many organizations (Hale and Borys, 2013; Martin et al., 2013). With this study, we contribute to the literature on rule breaking by providing insights into how groups defend themselves from top management's sanctions to persist in breaking decision-making rules. In this context, defending refers to the process of individuals coming together as a group to make decisions and/or take actions to reduce the likelihood (or minimize the extent) of top management's sanctions on the group for breaking a decision-making rule. Therefore, at least in the context of groups' breaking decision-making rules, our study provides insights into the mechanisms by which rule breaking persists.

Finally, research on group norms - "the informal rules that groups adopt to regulate and regularize group members' behavior" (Feldman, 1984: 47) — has increased our understanding of the acceptable and unacceptable workgroup behavior within organizations (Bettenhausen and Murnighan, 1991; Ehrhart and Naumann, 2004). Given that group norms can develop from explicit statements from co-workers (Feldman, 1984) and other group-member interactions (Cialdini and Trost, 1998), by studying the discussions among group members that lead groups to break decision-making rules (i.e., rallying tactics) and defend this rule-breaking behavior (i.e., defending postures), this study offers insights into the norms of developing and perpetuating norms of breaking decision-making rules.

\section{THEORETICAL BACKGROUND}

Behavioral theories of organizations focus on decision making in the context of bounded rationality (Cyert and March, 1963; Simon, 1947). To cope with this bounded rationality, top managers can mindfully anticipate the long-run consequences of alternate courses of action (Gavetti and Levinthal, 2000) to create decision rules that help guide and inform lower-level employees' actions (Simon, 1947; Gavetti, Levinthal, and Ocasio, 2007). Although the term rules has been applied in many different ways and contexts, we follow Morrison (2006, p. 6) in the organizational context and focus on those rules that are "an explicit organizationally defined policy, regulation, or

This article is protected by copyright. All rights reserved 
prohibition pertaining to how members of an organization are supposed to execute their jobs (March, Schulze and Zhou, 2000) and for which there is a reasonably wide consensus, legitimacy, and enforcement." These rules are formal (Lehman and Ramanujam, 2009; March, 1997) in that top management imposes and enforces them (Ouchi, 1980) such that when employees break the rules, they are vulnerable to sanctions from top management, such as reprimand, writeup, or even termination (Hale and Borys, 2013; Tyler and Blader, 2005). Thus, rule breaking refers to the "intentional violation of an explicit organizationally defined policy, regulation, or prohibition" (Morrison, 2006, p. 6). In this way, decision rules focus organizational members' attention on issues and answers that are critical to the continued enactment of the organization's current strategy (Ocasio, 1997, 2011).

Rule breaking often occurs when employees feel angry, hostile, and socially excluded (Judge et al., 2006; Twenge, Catanese, and Baumeister, 2003) and act in a self-interested, deviant, or unethical manner (Griffin and Lopez, 2005; Renn et al., 2005; Robinson and Bennett, 1995; Vardaman, Gondo, and Allen, 2014). Research on unethical behavior has mostly focused on the factors that lead individuals to break rules (Gino and Wiltermuth, 2014), such as egocentric defaults (Epley and Caruso, 2004), bounded cognitive capacities (Chugh et al., 2005), and moral disengagement (Detert, Trevino, and Sweitzer, 2008). For example, in the 1990s some life insurance companies violated government rules and regualtions by engaging in churning — "a practice in which the built-up cash value of existing [life insurance] policies is used to finance new, more expensive ones" to generate higher commissions for agents at the expense of policyholders (Mac Lean, 2001: 167). Although rule breaking within organizations is common (Hale and Borys, 2013; Martin et al., 2013), not all rule breaking is aimed at fulfilling self-interests; some rule breaking is based on the desire to benefit the organization and/or one of its stakeholders (Morrison, 2006). For example, one manager described a time when "he gave a subordinate a higher rating on his formal review than his performance warranted. The respondent wanted to give the subordinate time to look for a new position while still employed. He explained, 'I did this because I wanted to give the guy as much time as possible to find something and be able to take care of his family"" (Morrison, 2006: 13).

Rule breaking is important to understand from an organizational perspective (Morrison, 2006; Vardaman et al., 2014). As Blau (1955: 2) noted, "the task of organizational analysis . . is to 
understand the real (i.e., informal) organization as it emerges from the ideal (formal) one." A deviation between the informal and the formal appears to be particularly salient in tasks involving high uncertainty. For example, although the Forestry Service has clear rules to ensure the safety of its employees when fighting fires, the high complexity and uncertainty of fires mean that individual firefighters often violate the rules to achieve the objective of putting out fires (Desmond, 2007). Similarly, organizations often have rules for innovation (e.g., stage gates and resource allocation) that members sometimes violate to accommodate new information and advance projects (Olin and Wickenberg, 2001). However, it is not just individuals that make decisions within organizations, including the decision to break rules; groups have become an increasingly important means of organizing within firms. ${ }^{2}$

Individuals can join together to become a group, and groups become more effective when they are coordinated (Cohen and Bailey, 1997; Gladstein, 1984; McGrath and Argote, 2001; Tannenbaum, Beard \& Salas, 1992). Coordination refers to a "temporally unfolding and contextualizing process of input regulation and interaction articulation to realize a collective performance" (Faraj and Xiao, 2006: 1157) and helps members act as a unified whole (Brannick and Prince, 1997; Van de Ven, Delbecq, and Koenig, 1976) to achieve a common goal (Okhuysen and Bechky, 2009). Group members engage in explicit coordination through planning and communication (Rico, SánchezManzanares, Gil, and Gibson, 2008), which are eventually reflected in the group's norms (Feldman, 1984). For example, communication can help coordinate members for group decision making by providing feedback and facilitating other information exchanges (Kraut and Streeter, 1995; March and Simon, 1958; Van de Ven et al., 1976). Given that a group is not the sum of its individual members (Klein, Dansereau, and Hall, 1994) and that groups are central to many important decisions within organizations, the purpose of the current study is to explore how groups come together and coordinate to break decision-making rules.

Therefore, although we are gaining an understanding of who is likely to engage in rule breaking for self-interest (e.g., Giacalone and Greenberg, 1997; Vardi and Weitz, 2004) and prosocial reasons (e.g., Dahling et al., 2012; Morrison, 2006), we still do not fully understand what triggers a group to break decision-making rules or what group rallying and defending mechanisms perpetuate this type of rule breaking. Because we know little about how members rally as a group to break 
decision-making rules and how this rule-breaking is perpetuated, we decided to use a qualitative approach for theory elaboration (Pratt, 2009) to gain a better understanding of the phenomenon and contribute to the rule-breaking literature.

\section{METHOD}

\section{Research Context}

We explored 169 group decisions on venture applications from entrepreneurs - the unit of analysis is the group decision. We explored groups in a government department whose task it was to decide whether or not to invest in ventures based on entrepreneurs' proposals. These groups were low in skill differentiation (i.e., group members differ minimally in attributes that explain future performance [Lovelace, Shapiro, and Weingart, 2001]), low in authority differentiation (i.e., members come to a consensus such that the group makes the decision [Manz and Sims, 1987]), and high in temporal stability (i.e., the group is stable, and membership changes infrequently [Joshi and Roh, 2009]). Government-based funding bodies are an excellent context to explore groups that break decision-making rules because venture funding typically results from group discussions that lead to a group decision, involves the investment of substantial resources, pertains to many diverse stakeholders, and has explicit and clearly stated rules developed and communicated by top management — namely, decision-making rules that are expected to be followed. Therefore, rule breaking is likely to be particular salient in this type of group because it is unlikely that any one individual can force his or her group to make a particular decision. We investigated the decision making of five groups belonging to a department mandated by the Swedish federal and regional governments to assess proposals for investment in entrepreneurial firms. To maintain anonymity, we named the groups Alpha, Bravo, Charlie, Delta, and Echo (and members with fictitious names starting with the same first letter of the group to which they belong). The mandate for the groups was to decide to invest (or not) in regional ventures that would help foster long-term profitability and growth. We chose these groups because their decisions resulted in substantial investments and the groups were willing to allow a team of researchers to observe their decision making.

The composition of the groups remained stable across the two years we followed them. Tenure for membership in the groups ranged from two to 25 years, with an average tenure of 16 years and an average member age of 54 years. All group members had a university degree, mainly in business

This article is protected by copyright. All rights reserved 
administration. There was a gender balance across the groups - nine females and ten males. The chairperson was female in three regional groups (Alpha, Delta, and Echo) and male in two regional groups (Bravo and Charlie). Again, because these groups are low in authority differentiation, the chairperson was no more powerful than others in the group - members came to a consensus and made group decisions. In total, our respondents discussed 169 venture applications from entrepreneurs, which is our unit of analysis. See Table I for details on the funding proposals for each group and the amount invested (if any). The range of investments was SK 4,200 (USD 470) to SK 1,700,000 (USD 190,000), with a mean of SK 298,000 (USD 33,000).

\section{Boundary Conditions from the Research Context}

Boundary conditions are the limits for the theoretical predictions of a model and thus help describe the generalizability or transferability of the theorizing across contexts (Busse, Kach, and Wagner, 2017). The boundary conditions for this study reflect our theoretical sampling decisions. That is, given the above research context, our subsequent theoretical predictions may not apply beyond the types of groups we studied here or to rule breaking that does not involve breaking decision-making rules. First, we investigated groups in a government department whose task it was to decide whether or not to invest in ventures based on entrepreneurs' proposals, and we found that these groups were low in skill differentiation, low in authority differentiation, but high in temporal stability (see Hollenbeck et al., 2012). Group processes are likely to be particularly salient in this type of group because it is unlikely that any one individual can dominate his or her group. However, our theorizing may not extend to groups that are high in skill differentiation, high in authority differentiation, and/or low in temporal stability. Second, these groups are embedded in a large government organization, so our theorizing might not extend beyond this organizational form. Third, in this study, we also focused on formal rules related to groups' resource-allocation decisions with substantial (but not severe) sanctions. Our theoretical predictions may not extend to informal rules, to formal rules that are not directed toward decision making, or to group decision-making rules that are not focused on resource allocation. Finally, the Swedish government context could introduce some distinctive cultural aspects, such as an emphasis on consensus decision making, prosocial benefits, and the role of government in funding entrepreneurial ventures. There may even be differences across departments within a government organization. For instance, our theoretical predictions on the rule breaking by groups

This article is protected by copyright. All rights reserved 
responsible for funding entrepreneurial ventures may not extend to the rule breaking of groups responsible for taxation, emergency services, and/or education or to groups in private organizations.

\section{Empirical Data}

Observations at meetings. In total, research observers took part in three sessions with each of the five groups (i.e., 15 meetings in total), which involved approximately 60 hours observing the group making decisions. The meetings lasted approximately three-and-a-half to four hours each and were structured as follows: (1) presentation of the venture proposal, (2) group discussion on the venture proposal, (3) investment decision, and (4) justification of the investment decision. The groups' assessments of each proposal followed a similar process. First, the entrepreneur submitted a proposal that detailed the venture, the purpose of the requested funding, a budget for how the investment would be used, and details on how the requested funding would enable the venture to enhance profitability and/or growth. Second, the chairperson assigned one or two group members to a particular proposal and collected additional information if needed. Third, the proposal was presented, discussed, and decided upon in a meeting by the group. Finally, the group communicated the decision to the entrepreneur. The discussion on a proposal ranged from five to 20 minutes, with an average of 12 minutes.

Internal documents, communications, and directives. The data for this study were derived from multiple sources at multiple points in the proposal-evaluation process: (1) pre-meeting materials, including the entrepreneurs' proposals, initial email instructions and reactions, and an agenda for the forthcoming meeting; (2) formal and informal discussions immediately before, during, and immediately after the meeting as well as field notes taken during the meeting and immediately after the meeting; and (3) documentation about the charter for the group, formal rules, and other website content from the governmental financiers. In Table II, we provide details about this documentation. At least one member of the research team (but usually two members of the research team) reviewed the proposals in advance of the meetings and attended the meetings in which the groups discussed and decided upon the funding for each proposal. The members of the research team did not engage in the discussions or influence the decisions in any way - they were passive observers, consistent with an ethnographic approach.

This article is protected by copyright. All rights reserved 
Insert Table I and then II about here

\section{Data Analysis}

Our analytical approach was highly iterative - we frequently cycled between reviewing the data and mapping the process and cycled between the emerging map of the process and our theoretical ideas. Specifically, we conducted a detailed analysis of rules, potential sanctions, and group rule breaking (and rule following) over time. We then engaged in an in-depth analysis of the different mechanisms underlying the different mechanisms underlying group rallying for rule breaking and the defense of this behavior. Finally, we investigated the mechanisms of rallying and defending to generate an overarching group model of the breaking of an organization's decision-making rules.

Analysis of group decision-making rules over time. After assembling all the data, we explored the groups' decisions for each proposal and then compared each decision-making instance to the formal rules the groups were expected to follow. We found instances of rule breaking and focused most of our initial attention on mapping the key activities that led to these rule-breaking decisions and the key activities following the rule breaking. Over time, we began to observe a pattern within the decision-making process that was relatively consistent across the different proposals and groups. This pattern became salient as we distinguished group decision making that broke the rules from group decision making that followed the rules. From this pattern, we formulated the researchers' narrative (Langley, 1999; Monin et al., 2013) of group decision-making, focusing on rule breaking in terms of its triggers, mechanisms, and responses. In approaching the analysis, we expected that we would need to "read between the lines" to detect and understand rule breaking, but we were initially surprised that this was not the case. In this decision-making context, group decisions were required, which in turn required discussions. By being privy to these discussions - as a "fly on the wall" — we overheard the thinking behind the decision making, which was made rather explicit by group members. As a result of this analytical approach, we uncovered 29 decisions that clearly broke the rules and another 19 decisions that appeared to break the rules. To confirm or disconfirm these initial classifications, we shifted our attention between the focal proposal, the formal rules, and the group members' discussion of the two. Again, although we focused our analysis and reporting on these instances of rule breaking, we used rule following for comparison. While it was technically possible for rule breaking to involve 
the group decision to reject a proposal that conformed to the rules, all instances of rule breaking in the data involved the group decision to fund a venture proposal that should not have been funded based on the organization's rules.

Analysis of the responses to rule breaking. Based on the above analyses, we focused on the group aspects of the antecedents and consequences of the decision to break the rules (with rule following as a baseline). Specifically, we began with open coding by identifying initial concepts related to the group aspects of rule breaking and categorizing those concepts. When possible, we used the language in the data to label the initial codes and categories. We then engaged in axial coding by identifying links between categories as a basis for aggregating them into second-order themes. Finally, we grouped second-order themes into aggregate dimensions, which form the basis of our group model of breaking decision-making rules. We illustrate the data structure in Figure 1. Although we have described the coding process as a sequence of steps, in practice, the process was recursivewe often circled back to reanalyze the raw data, initial codes, and second-order themes (consistent with Locke, 1996) and recoded the data at least five times.

Insert Figure 1 about here

Trustworthiness of the data. We took a number of steps to ensure the trustworthiness of our data (consistent with Lincoln and Guba, 1985). First, we collected and stored all documents as they became available to us. Second, we used a 24-hour rule to ensure that we recorded and stored all observation notes within 24 hours of the focal event (usually a meeting). Third, we conducted peer debriefing in two phases. In the first phase, the researcher who attended the meeting discussed the meeting with other researchers who did not attend but were aware of the purpose of the group. This interaction provided a basis for ensuring the key aspects of the meeting were recorded, helped "pull out" the major event details and interactions from the meeting, and began the process of identifying key themes. The second phase occurred during the axial coding stage: the researcher involved in coding the data introduced the first-order concepts and second-order themes, and a researcher unfamiliar with the project asked questions about relationships, which helped with subsequent coding 
and the development of aggregate dimensions. These outsiders provided new insights to enable those closest to the data to move from seeing the trees to also seeing the forest.

\section{GROUPS' BREAKING DECISION-MAKING RULES TO FUND VENTURES}

\section{Top Management's Rules for Acceptable Proposals to Fund}

The members of the groups studied were appointed by the Minister for Industry, Sweden. The charter for the groups was stated by Albert as follows:

We finance investments in buildings, machinery, inventories, marketing, education, acquisition of consultancy services, and innovation development in small- and medium-sized ventures [defined on the web as ventures with fewer than 250 employees and turnover lower than 50 million euros]. Our system aims to help ventures to reach sustainable growth. The aim is to foster regional growth, create employment opportunities, and assure the provision of regional services. Finance is provided to ventures in accordance with ethical and competitive requirements. The funding of projects should not contravene the European trading conditions-not favor Sweden's products and services over exported products and services. Operational costs are not financeable. Distribution of finance is divided into geographical areas: first-order and second-order prioritized areas, sparsely populated areas, and rural areas. The scope of funding is decided individually based on each venture application and depends on factors such as the amount of investment requested; geographical area of the business; as well as the company's ability to become profitable, accomplish growth, and contribute to new jobs and employment opportunities in the region. We are also strictly forced to follow European Union regulations.

The government had specified a number of rules for the groups to follow when assessing entrepreneurs' proposals, and the groups understood these rules. We inductively categorized the rules into four types. (1) Geographical scale rules refer to only investing in entrepreneurial ventures operating in the particular region. An example of a reflection on a geographical rule is "we can only finance entrepreneurial ventures in this region, not in other regions." (2) Financial scale rules refer to the ventures' financial situations. On one hand, ventures should not be too financially strong, but on the other hand, they should not be too financially weak. Some uses of these financial rules include "we can't finance ventures able to carry out the investments themselves" and "we are not allowed to 
finance investments in ventures risking bankruptcy." (3) Competition scope rules refer to financing ventures without distorting the nature of the industry. An example of one of these rules is not to finance ventures if there are regional competitors that may be disadvantaged from the investment. (4) Other scope rules refer to the type of investment and purpose of the investment. An example of a (non-competition-based) scope rule is that top management allowed the groups to finance machinery but not vehicles.

\section{Motivation to Follow the Decision-Making Rules}

These rules were formulated and administered from the top down (i.e., from the Minister's office), and the groups were expected to follow these rules when performing their duties. The groups understood the nature of these rules, the importance the government placed on these rules, and the expectation that they would be followed. The members also acknowledged the potential costs of not following the rules.

First, top management could sanction the groups by diminishing their professional role. Indeed, group members were threatened by the possibility that their autonomy and independence could be curtailed as a punishment for breaking the decision-making rules. For example, top management could reduce the maximum investment the groups were allowed make and/or reduce the total pool of funds to be invested. Group members felt that such restrictions adversely impacted the groups' power and status - social attributes highly valued by group members. For example, as the result of past decisions, one member of Bravo noted how his group was transferred to a "manager who keeps his eyes on us and has a very strong hand in the direction the group takes." In Delta group, the decision scope had been reduced such that "nowadays, decisions of this size [i.e., the amount of funding] goes to top management; they want to be assured that they can stand behind the decision made" (David).

Second, top management could officially reprimand the groups for breaking decision-making rules. In this study, sanctioning typically came from either the Human Resource Disciplinary Board (for the most serious cases or for serial offenders) or an internal auditor. Bodil described the internal auditor's reprimand: "She [the internal auditor] found a few cases where the rules were not followed." The internal auditor then met with the manager who had direct responsibility for the group and gave him a verbal reprimand, and the group received a written reprimand, which was included in each 
member's employment file. With an official reprimand, a "wrongdoing” could become widely known (within the government and, to some extent, externally), and members expected such punishment to generate feelings of considerable shame and embarrassment. These group members valued others' viewing them in a positive light and seeing themselves in a positive light, which would be undermined by an official reprimand. The anticipation of shame and embarrassment thus represented a salient consequence of rule breaking for group members.

Third, to the extent that the public became aware of rule breaking, there was likely to be backlash against the responsible group, the department, and perhaps the program. Group members acknowledged that if the media published articles against a group, it would result in a "very bad" situation. In one instance, Dagny felt that her group was being "hunted by the media," and in another instance, Bert expressed "fear of officially being accused." More generally, group members reflected on past decisions, asking, "What could happen if . . ?" (Cecilia) and then thinking, "I could not even imagine how horrible that would be" (Eva). Moreover, in reference to group members' family feeling the media heat, one member reflected, "I would never want anything like that to happen to my relatives" (Eva). Indeed, some entrepreneurs who were turned down for funding threatened to go to the media: "He called me and yelled at me on the phone since his application was dismissed. He threatened to go to the press since he knew that others in the same situations had been approved finance while he wasn't" (Bert). The media had reported on rule breaking in the past, which not only triggered negative public reactions but also led top management to enact other sanctions, such as officially apologizing for the offending group's behavior in front of the media and important others, which again shone a spotlight on the focal group's wrongdoing, likely stimulating feelings of shame and embarrassment and negatively impacting group members' career trajectory. For example, Anton commented, "We need to think about our reputation to have a potential life in this business afterwards as well," and Bo was also concerned about his reputation: "We want them [entrepreneurs] to appreciate our work. Negative reactions from entrepreneurs are spread around to others in our environment, and this is not good for our reputation. We are all dependent on our reputation."

Fourth, group members also realized the threat of legal action by certain entrepreneurs who were denied funding given their knowledge of past entrepreneurial projects that should not have been funded (based on the rules). Legal action against the groups' decisions was seen as a direct challenge 
to the members' professionalism, ethics, and ability to effectively perform their job. Such action could also shine a light on both the individual members and the focal group's past decisions, placing group members in further jeopardy (organizational, public, and legal) and magnifying feelings of shame and embarrassment.

Finally, whether sanctioned by top management (reduced autonomy or official reprimand), the public (public backlash), or the legal system (legal action), group members recognized that these sanctions for breaking decision-making rules would likely have a substantial negative impact on their career. Career progress was important to these individuals and to have career progress curtailed would have been devastating. For example, an official reprimand may exclude (or at least slow) promotion and may also reduce opportunities to change jobs within or outside the government. In more extreme cases of rule breaking, the Human Resource Disciplinary Board could terminate an individual's employment contract and pursue criminal charges.

\section{Motivation to Break the Decision-Making Rules}

As described above, the groups faced pressure (i.e., via sanctions) to follow top management's rules for deciding whether or not to allocate funding based on an entrepreneur's proposal. However, for some proposals, the groups broke the decision-making rules. That is, group members recognized the high costs of possible sanctions for breaking the rules but were still sufficiently motivated to break the decision-making rules - that is, they were willing to bear the sanction risks. Group members described the proposals for which they were willing to break the decision-making rules, which revolved around three anticipated effects of not funding a focal proposal: (1) self-related effects, (2) venture-related effects, and (3) other-related effects.

Self-related incentives. The first trigger of rule breaking involved anticipating the effects of funding and not funding an entrepreneur's proposal on the individual decision maker and/or on the decision-making group. For example, the decision makers expressed fear of the consequences for them if they were to turn down a powerful actor's application. The following discussion by Echo group highlights the tension between following the rules and upsetting a powerful entrepreneur:

Einar: We do not finance such machinery. He is upset. He threatens to close down everything; he says that we don't understand anything or how it works or what they need. You should meet him; he is fantastic. I told him that I will bring it up for discussion since he gets

This article is protected by copyright. All rights reserved 
very upset when he can't get what he wants. I told him that this kind of machinery is not so easy to sell. He yelled, "This is easy to sell. I have heard that so many times! Say it no more!" Eva: But we cannot finance just because he is screaming. Einar: Yes, we become more engaged then. Eva: We are caught in this. All group members concurred: Yes, that's right.

Entrepreneur- and venture-related incentives. The second trigger of rule breaking involved the anticipated effects of the groups' decision alternatives (e.g., how turning down a proposal would adversely impact the focal venture and, ultimately, the entrepreneur and his or her family). The groups' thinking and interactions with the entrepreneurs stimulated emotions that appear to have impacted the decision to break rules to fund some entrepreneurs' proposals. This form of rulebreaking trigger is illustrated by the following comments in different proposal discussions: One member of the Charlie group noted that he "visited them [the entrepreneurs] and met the daughter and saw that they should receive finance. I felt it." Another group member for a different project noted, "We are kind making this decision." Similarly, the tension between following the rules (not funding a venture) and feeling sympathetic toward an entrepreneur is reflected in the following exchange by the members of Bravo:

Britt: It would feel right to finance a tractor [funding vehicles is against the rules]. Bert: It sounds more like a concept. It is like a symbol, an image. Birgitta: Yes, it's special; you don't buy a veteran tractor; it's not practical, it's loud, smells disgusting, and uncomfortable. Bo: It's not machinery; it's a symbol, and he needs this [symbol]. Bodil: That's for sure.

Other-related incentives. Anticipation of the benefits to "others" from funding the proposal was the final rule-breaking trigger. Anticipated benefits to others came in a number of forms. First, sometimes funding a proposal would help the environment, as in the following conversation within Alpha group:
Albert: People want this type of machinery. It is more environmentally friendly and lowers levels of noise. Anton: We are not allowed to finance this type of machinery, but we have made our own interpretation and have decided to have a practice of our own for this type of machinery. Axel: Yes, we want the machinery to be more environmentally friendly. Anna: This is a highly irregular activity, but we want them to become more environmentally friendly.

This article is protected by copyright. All rights reserved 
Second, funding certain proposals would also help the local community economically. For example, the discussion for one proposal for the Charlie group proceeded along the following lines: "The car industry is particularly valuable since it provides so many employment opportunities and thus is critically important for the region. We can stretch our decision in such cases [to depart from the rules]." For another proposal, Bo argued that "it would be possible to finance a restaurant in the very rural areas" (despite restaurants being against the rules), and for another project, David argued, "It's positive that [a high-impact company] buys from local entrepreneurs and keeps jobs in the region."

Finally, funding certain proposals would help build local competences that would have "flowthrough effects." For example, Bravo's discussion for one project proceeded as follows:

Bo: There are mitigating circumstances in this case. ... They are about to develop the venture for selling service packages to [a high-impact regional company]. They have contracts with them, and [the high-impact regional company] is interested in having a location close to their business. It is not produced here; it's produced in Germany. Bengt: We must support this [despite it being out of scope]. It supports competence in the local industry, and that's good.

Although group members considered the anticipated effects of their decisions on themselves, the effects of their decisions on entrepreneurs/ventures and on others largely stimulated rule breaking. However, implementing this rule breaking still required steps for rallying members of the group to impact the funding decision, to which we now turn.

\section{Rallying Group Members}

As indicated above, there were conflicting incentives between following the decision-making rules and breaking those rules. Indeed, there were some instances of initial conflict between group members over breaking the decision-making rules. When an individual member raised the issue that a decision to fund an entrepreneurial proposal broke the decision-making rules, in some instances, the focal group (including the individual who raised the issue) decided to break the rule for the "greater good," and in other instances, the other members hesitated to respond to the direct claim of rule breaking and focused on the reasons for funding the proposal until all members (including the individual who raised the issue) agreed to fund the project. There were also instances when a member

This article is protected by copyright. All rights reserved 
raised the issue that funding a proposal would break the decision-making rules and the rest of the members agreed to reject the proposal consistent with the rules.

It was when the net benefits of breaking a rule were greater than the net benefits of following the rule that tension arose in the groups between what they were motivated to do and what they knew top management expected them to do. To deal with this tension from wanting to go against top management's decision-making rules, the groups often began rallying. Rallying in this context refers to the process of individual members coming together to form a group to break a decision-making rule. The primary tactics for rallying the group to break the rules to fund an entrepreneurial venture were (1) twisting interpretations of the rules, (2) exceptionalizing the current proposal, (3) claiming chaos and arguing that the rules were out of date, and/or (4) making selective historical claims. We now discuss each in turn.

Twisting interpretations of the rules. A rallying tactic for group rule breaking was twisting the interpretation of a rule, the entrepreneur's proposal, or both. For example, one rule was to not fund mobile machines - the rules allowed for funding only fixed machinery. The Bravo group twisted the interpretation of "mobile" so that they could fund one particular project. Specifically, Britt noted that they had previously rejected a similar proposal by this entrepreneur: "Last time, we argued that they are out traveling with the machine [so the proposal was denied]. But it [moving the machine] is only a minor part of the time [the machine is used]. They mainly work at home." Bo twisted (or redefined) the notion of mobile even further: "[The entrepreneur] has several plants, and it would be possible to move equipment between them. This is only a problem if they move equipment to another region." Birgitta then added, "So it's not that mobile after all, and the venture also offers other services too."

Another means of twisting the interpretation of the rules was to omit a criterion (fundamental to the rule) from discussion and group consideration or to include a new criterion that "justified" rule breaking. There were numerous times when the groups acknowledged but then ignored criteria consistent with the rules. For example, they ignored the rules of not funding entrepreneurs who had previously defaulted on their debts, of not providing funding for an entrepreneur's private residence, of not funding service firms, and of not funding entrepreneurs who could self-finance. In addition to ignoring rule-appropriate criteria, the groups sometimes introduced new criteria to engage in rule breaking. In one exchange, group members acknowledged a rule but were able to justify breaking the 
rule to themselves by adding a new criterion (as a moderator) - the stage of venture development. More specifically, the following conversation by the Echo group involves both twisting interpretations (of inventory) and introducing a new criterion (adjusting the rule because the venture was in the start-up phase):

Einar: To be crass. An inventory should be of the venture's inventory list, be part of the balance sheet, and be depreciated between one and five years. Yes, that's right. So, to be square, that's the rule. Eva: Yeah, but that's [the definition of inventor] incredibly narrow. But we can accept [the proposal]. We used to say that the first machine may be a smaller amount. Then it's ok if we say so [reinterpret the entrepreneur's inventory]. Einar: Yeah, if it is the start-up phase.

Exceptionalizing the current proposal. Exceptionalizing was another rallying tactic that freed the group decision from the rules provided by top management. Claiming that a current proposal was an exception implied that the rules (created elsewhere) were not sufficient or fine grained enough to apply to that special or otherwise extreme case. Carl of Charlie group noted that one "project is just so beautiful, and he [the entrepreneur] is so service minded. It is fabulous!" He then circulated pictures of the project around the room. Cecilia then noted, "It is such a wonderful accommodation; it is special. We really need to be able to give it [funding] to him." The conversation continued with comments like "he is wonderful," "he is such an artist," and "he is certainly a survivor."

Claiming that the rules are out of date. Another rallying tactic was claiming chaos because the rules were out of date. By claiming chaos, the groups were free to conclude that the rules no longer applied to the current proposal in the current situation and that they could thus rely on their own judgments unconstrained by such rules. For example, Albert of Alpha group said the following: "This situation is out of our hands. We need to rely on our intuition. We can't lean on the rule; it doesn't fit this situation." This rallying tactic removed the relevance of the rules such that because times had changed, the rules no longer applied and thus should not be used. Another example is evidenced in Eva's statement: “This rule is outdated. It doesn't fit society of today. We need to start developing new practices to catch up."

Making selective historical claims. Finally, members used historical decisions selectively as a means to justify and thus rally the group for breaking decision-making rules. This approach appears to 
have been effective because it gave the impression of continuity and reliability in the groups' decision making (despite the decision to break the rules). Group members referred to past decisions, often saying things like "we accepted it last time" (Bodil), and they commented on how previous decisions impacted current decisions: "We can't dismiss it just because it's not fixed. It's not valid. It would have been easier if we had kept to the rule earlier. Then it [to say no to the proposal] might have been ok. Now we have departed from that criterion" (Anton).

\section{Groups' Rule Breaking to Decide on Funding for Entrepreneurial Ventures}

Despite awareness and knowledge of the decision-making rules, the groups sometimes broke them. The groups broke the geographical rules by, for example, investing in ventures with manufacturing in another region. They broke the financial rules by, for example, financing investments in companies able to carry out the investments on their own. They broke the competition rules by, for example, financing investments in a venture that would likely disadvantage regional competitors. They broke the scope rules by, for example, financing investments in vehicles. In breaking the rules, the groups faced possible sanctions, but they also took defensive postures to avoid or minimize the extent of those sanctions.

The groups used the same criteria but varied in the emphasis they placed on these criteria in rallying to break the decision-making rules - that is, groups varied on their emphasis on (1) entrepreneur-related benefits, (2) other-related sustainability benefits, (3) regional-development benefits, and (4) self-related benefits from placating large powerful companies in the region.

Therefore, groups were more likely to rally to break the decision-making rules to fund proposals that aligned closely with the criteria they emphasized.

\section{Defensive Postures to Avoid Sanctions for Rule Breaking}

The groups pursued various defensive postures to avoid sanctions for breaking the decisionmaking rules, including (1) ignoring the rule breaking, (2) blaming external others for the rule breaking, (3) confessing and seeking forgiveness, (4) making amends for the rule breaking, and (5) correcting to avoid future rule breaking. These responses are somewhat ordered in terms of increasing proactiveness.

Ignoring the rule breaking. The groups' usual first response to breaking a decision-making rule was to collectively deny that any rule breaking took place. This action is equivalent to the ostrich 
putting his or her head in the sand in the presence of a threat. Many times, evidence of this response in our context was the absence of any other form of response. Indeed, in some cases, the rule breaking was never really raised again. For example, Claes (Charlie group) stated, "Let's continue. This will be forgotten soon. Nobody will bother." This represents a defensive posture because by ignoring the event (i.e., the rule breaking), the groups hoped that the situation would not draw top management's attention, enabling them to avoid sanctions.

Blaming external others for the rule breaking. The second response involved acknowledging the rule breaking (unlike the ignoring response) but attributing blame for the decision externallynamely, to conditions beyond the groups' control and/or to others outside the groups. By blaming others, the groups were attempting to absolve themselves of responsibility for breaking the decisionmaking rules. For example, in a conversation, one member stated, "We did not take part in the decision at all. It was our former colleague who made it, and we can't change it. We don't even know why he did it." In other instances, the groups acknowledged rule breaking but believed that it was no longer in their power to change the decision, which is best illustrated by the following conversation in Alpha group:

Axel: There is a lot of trouble with entrepreneur Kesler. Anna: We are on the wrong track. He has fooled us. He has not been open about his intentions with us. Alva: We need to tell everyone that we have been fooled. Anton: We don't want to be discredited [for this funding decision].

Confessing and seeking forgiveness. This response involved informing top management (as the governing body) of the rule breaking and simultaneously apologizing for the decision-making mistake. The groups confessed their rule breaking as a way to get out in front of the story. For example, Alpha approached the internal auditor to help the group deal with rule breaking; by going to the internal auditor directly and early, the hope was that she would be lenient in sanctioning the group. Although the auditor introduced new processes that diminished the group's autonomy (e.g., using a check list in decision making), the group faced little else in the way of sanctions. Consistent with this defensive posture, Carl (Charlie group) concluded that it is better "we ask for forgiveness than permission."

This article is protected by copyright. All rights reserved 
Making amends for the rule breaking. This response not only acknowledged the breaking of a decision-making rule but also had an element of remorsefulness in the approach - a basis for redemption. In one instance, the group's response was to make amends by redirecting resources. In referring to Alpha's decision to redirect resources to make amends for a problem created by breaking a decision-making rule, Alva noted, "We can always use that freedom even though it is not supposed to be used that way. Still, if we keep this [freedom to shift funds], we can guide the rest to another problem.” Albert then replied, “Absolutely, then we get rid of this problem.” Interestingly, in making amends for one problem, the group broke another decision-making rule.

Correcting to avoid future rule breaking. The final defensive posture was to acknowledge the group rule breaking, learn from the experience, and modify the decision-making process. In one case, Delta group decided to make a rule explicit to those creating proposals by including a footnote in future contracts stating, "We do not contribute to over-investment." In some ways, this correcting response is also consistent with blaming in that it implies that the entrepreneur has the power to conform with the rule or not (which may be the case, but it seems to redirect attention for rule breaking from the group to the entrepreneur). Another example of correcting was not so much modifying the groups' behaviors toward the decision-making rules but changing the rules themselves. Combined with confessing and seeking forgiveness, the groups often sought to correct the decisionmaking process by explaining the situation to top management and convincing them to lobby for a rule change from the governing body. The goal of this behavior was largely to bring the rules into alignment with the groups' decision making rather than the other way around. For example, on one occasion, Echo group acknowledged the need to change the rules: "[The rule] is too rigidparticularly in this case" (Eva). To which Einar responded, "There may be some potential corrections in the rules that may make it work."

\section{Primary Pathways of Groups' Breaking Decision-Making Rules}

Self-interested pathways of groups' breaking decision-making rules. As illustrated in Figure

2a, our findings highlight that self-related interests triggered the groups to break two types of decision making rules - financial rules and competition rules. Specifically, the groups broke financial and competition decision-making rules because members believed that the groups' own interests would be vulnerable to attack by powerful actors. For example, powerful regional companies and individuals 
demanded and were granted a voice to make the case for their proposal, and they used that voice to make it clear that they were not going to take "no" for an answer. These regionally powerful actors were most concerned about financial and competition rules because given their regional and social position, they were well equipped to meet the geographic and scope criteria for funding. However, given their power and size, they ran the risk of being too financially strong to receive funding (in contravention of the financial decision-making rules) and could use their power to distort the market (in contravention of the competition rules).

To break these decision-making rules, the groups chose to exceptionalize, make selective historical claims, and/or twist the interpretation of the rules. Given these powerful applicants' prominence in the region, it was relatively easy for the groups to distinguish these individuals from other applicants and make the case to themselves that these applicants were worthy of special consideration (exceptionalize). Furthermore, either these regionally powerful actors or similar regionally powerful actors had benefited from rule breaking in the past, which made it possible to make selective historical claims about why the rules should not be followed in comparable instances. Again, because of the distinctiveness of these regionally powerful applicants, the groups either captured that distinctiveness by adding a criterion or made the case for why a criterion should not be used - in both instances, the process "enabled" the groups to break financial and competition decision-making rules.

Interestingly, while concerned about the implications of following the decision-making rules (receiving the wrath of powerful regional actors), the groups were not overly concerned about the possibility of sanctions for breaking the decision-making rules, confident that the decision would be externally legitimated. Therefore, the groups' defensive posture was to simply ignore that they broke the decision-making rules.

Entrepreneur-/venture-interested pathways of groups' breaking decision-making rules. As illustrated in Figure 2b, our findings highlight that interest in the well-being of an entrepreneur or yenture triggered the groups to break three types of decision-making rules-finance rules, competition rules, and scope rules. When it came to breaking decision-making rules for the benefit of an entrepreneur and his or her venture, the groups were highly focused on demonstrating support for the entrepreneur by granting the requested funding. They were supportive of an entrepreneur largely 
because they trusted him or her and/or wanted to reward the entrepreneur's passion for the venture. Indeed, given the trust and belief in the entrepreneur's passion, granting funds was almost seen as a moral imperative - a moral imperative greater than following the decision-making rules. This feeling of support was mostly targeted toward local entrepreneurs, and by being local and mostly small, these applications rarely fell outside the geographic rules. Therefore, the geographic decision-making rules did not need to be broken.

The groups in these pathways broke competition decision-making rules most often. Although these rules were included to ensure that the groups did not fund ventures that could disadvantage existing regional players, it appears that the groups empathized with some entrepreneurs (through strong bonds of trust) and felt that it was important to reward these entrepreneurs' strong motivation with funding despite the possibility that such funding (a reward for these entrepreneurs) could penalize other regional firms. It appears that some entrepreneurs' needs were more salient to the groups than the more abstract, distal, and potential harm created to others, and this salience encouraged the groups to break this decision-making rule. Breaking decision-making rules on competition generated a diversity of rallying mechanisms. The mechanisms of twisting the interpretation of the rules and exceptionalizing for rallying the group to break the decision-making rules all led to the defensive posture of ignoring the rule breaking. These mechanisms were often used in concert to magnify their rallying effect. Making selective historical claims to rally the group led the groups to defend themselves by going on the attack and blaming external others for the funding decision. By claiming chaos or arguing that rules are out of date to rally the group, the groups enacted a defensive posture that acknowledged the rule breaking by confessing and seeking forgiveness, or they worked toward either making amends or correcting the process for subsequent decision making.

The groups also broke finance rules. Given the small size of many of these entrepreneurial ventures, some faced the risk of bankruptcy or payment defaults (in contravention of the finance decision-making rule). However, given their high levels of trust and belief in some entrepreneurs, the groups occasionally ignored "offending" the financial criteria so that investments could be made. Given these ventures' smaller size and the groups" "faith" that these entrepreneurs would be able to deliver, the groups believed that if they ignored the rule breaking, then no one would find out about it. 
The groups also broke decision-making rules on scope in the interests of entrepreneurs and their ventures. Again, because they trusted and empathized with some entrepreneurs and wanted to reward these entrepreneurs' passion, the groups were willing to break the decision-making rules on how investments were to be spent. The groups were rallied by the mechanisms of twisting the interpretation of the rules, which in turn activated a defensive posture that involved ignoring the rule breaking in the hope that no one would notice. However, the groups also sometimes made historical claims to rally scope-related rule breaking, which was associated with the defensive posture of blaming external others for the "necessity" of breaking the decision-making rules. Interestingly, the groups often used more than one means to rationalize breaking decision-making rules in the interests of entrepreneurs. Specifically, they frequently overstated the needs of entrepreneurs and legitimated satisfying these needs by twisting the interpretation of the decision-making rules including introducing new criteria and making exceptions (including the exceptions to add new criteria).

Other-related pathways of groups' breaking decision-making rules. When the groups decided to break the rules in the interest of helping others, what was unique was not so much the type of decision-making rules broken (i.e., geographic, financial, or scope rules) or even the mechanisms used to rally group members (twisting the interpretation, ignoring/introducing criteria, claiming chaos, and exceptionalizing) but the fact that the groups used only one type of defensive posture (see Figure 2c). To defend themselves, the groups ignored their rule-breaking behavior. Breaking the decisionmaking rules was legitimated by the groups - a natural way of acting for groups that had the best interest of society at heart. The benefits from funding these proposals were considered universal, so the funding of such projects was prioritized over everything else, including the decision-making rules.

Insert Figure 2, 3 and then 4 about here

\section{A GROUP MODEL OF BREAKING DECISION-MAKING RULES}

The rule breaking associated with the investment decisions made by groups from a Swedish government funding agency reveals a pattern of rallying group members to break decision-making rules and then adopting a defensive posture to protect the groups from sanctions. While these illuminating examples have unique characteristics, the pattern we uncovered is also likely to hold for 
other group decisions and actions that deviate from top-down directives, especially rule breaking (Dahling et al., 2012; Morrison, 2006). Next, we formulate a model explaining how this pattern surfaces to further clarify group rule breaking at a more general level (see Figure 3) and specific to tensions (see Figure 4).

First, we focus on the tension between motivations to follow decision-making rules and motivations to break these rules - a tension that explains the triggers for rallying the group. Second, we concentrate on the rallying tactics that explain how members come together to enable groups to break decision-making rules. Third, we discuss how a group's breaking of a decision-making rule necessitates a defensive posture to avoid or minimize sanctions on the group. Fourth, we highlight how defensive postures typically obstruct top management's decision-making rules from being updated or improved. Finally, we highlight how sanctions for breaking decision-making rules impact groups' subsequent rule breaking.

\section{Tension between the Motivations for Following and Breaking Decision-Making Rules}

A group faces little tension when the motivation to follow decision-making rules exceeds the motivation to break these rules - that is, when top management and the group are aligned, and the rules are followed (e.g., Tyler and Blader, 2005). However, tension is created when the motivation to break a decision-making rule exceeds the motivation to follow top management's decision-making rules - that is, when the incentives introduced by top management (i.e., sanctions for rule breaking) and the group's incentives are not aligned. Although not the case with the groups studied here, research has found that not all rules are contested and that rule breaking may even be permitted by top management (i.e., a mock bureaucracy) (Gouldner, 1954; Martin et al., 2013). In other words, when groups have minimal incentive to follow decision-making rules (e.g., weak enforcement of sanctions) and substantial incentive to break these rules (e.g., rule breaking generates considerable benefit for the organization), there is little tension, and groups will likely engage in rule breaking.

In terms of tension, previous studies on counter-productive work behaviors in general (Fox, Spector, and Miles, 2001) and rule breaking specifically (e.g., Dilchert et al., 2007) have acknowledged tension between organizations (in this case, top management's decision-making rules) and employees. Our findings complement this research by demonstrating that tension arises when a group's perceived benefits from breaking decision-making rules exceed the group's perceived costs of 
top management's sanctions from breaking the decision-making rules. This tension can trigger rallying members for group action. As our cases illustrate, decisions over funding entrepreneurial ventures can create tension between the incentives to break the rules and the anticipated sanctions from doing so, and dealing with such tension is generally a priority for group members in the initial decision-making stage. This tension frequently indicates a distinct need to consider top-down directives in light of employees' motivations. As our cases show, groups' motivations can be driven by self-interests and/or the interests of others. Indeed, decision-making rules may be particularly difficult to follow in the presence of information about the uniqueness of a particular situation (Dobbins, 2009; Martin et al., 2013). Furthermore, the more proximal decision makers are to bottomup information (e.g., others being impacted by the group decision), the more likely they are to rely on that information (Tversky and Kahneman, 1973). As a result of their reliance on salient available information (Ocasio, 1997; Tversky and Kahneman, 1973), groups' focus tends to shift toward breaking decision-making rules (and a willingness to bear the risk of sanctions) to benefit themselves or others.

Therefore, our findings provide some explanation for groups' emphasis on bottom-up information for specific decisions. Nevertheless, this explanation does not completely clarify how the motivation to break decision-making rules becomes a group decision, thus indicating the need to investigate the mechanisms by which members are rallied to become a group for this purpose.

\section{Rallying Group Members}

Although tension between top management and a group can lead the group to break decisionmaking rules, research has highlighted that many decisions and actions within organizations are made by groups (Cordery, Muellerm, and Smith, 1991; Gibson and Earley, 2007). These actions include rule breaking (Edwards and Wajcman, 2005; Sallaz, 2009), for which a group is often different from simply the sum of its parts (Klein et al., 1994). Becoming a group for a specific decision, especially when it involves a conscious intent to deviate from top-down directives, requires "rallying the troops"- uniting individuals as one. However, our findings of rallying group members is different from findings of managers' rallying employees (e.g., CEO leadership [Ashkanasy and Daus, 2002]) because it occurs despite top management's directives. Our cases demonstrate how group members rally to become a group ready to break management's decision-making rules. 
Specifically, our findings highlight tactics — used alone or in concert — that bring a group together to break decision-making rules. Each rallying tactic provides a rationale for deviating from the rules. Research has provided us an understanding of how individuals can rationalize immoral decisions and actions even when those decisions and actions violate their personal morals (e.g., moral disengagement [Bandura, 1999; Jetten and Hornsey, 2014; Martin, Kish-Gephart, and Detert, 2014]). Our findings complement this stream of research by explaining how individuals come together as a group through the use of one or more of these rallying tactics. In our cases, the members were rallied by reinterpreting the decision-making rules to minimize or nullify deviation from them (i.e., twisting the top-down directives), asserting the decision-making rules' lack of relevance for the current task (i.e., exceptionalizing) or the current situation (i.e., updating), and selectively remembering (i.e., cherry picking from history). Although research has focused on how individuals rationalize their deviation from norms or values for unethical decision making (Detert et al., 2008; Shepherd, Patzelt, and Baron, 2013) and behavior (Bandura et al., 1996; Shu, Gino, and Bazerman, 2011) to the benefit of themselves and to the detriment of others, we found that some tactics can be used to rally a group to break decision-making rules to benefit others, such as entrepreneurs or the community. Regardless of whether group members are motivated to benefit themselves or others, these rallying tactics are a means to ensure that all members of a group are of one mind in pursuing a decision that deviates from top-down directives.

\section{Groups' Breaking Decision-Making Rules and Defending against Sanctions}

Our findings also show that group decisions sometimes involve disregarding (through rallying) top management's decision-making rules in favor of addressing bottom-up incentives (regardless of whether self-interests or prosocial interests drive those incentives). Although top-down directives can specify "acceptable" autonomy within predetermined boundaries (Bingham and Eisenhardt, 2011; Brown and Eisenhardt, 1997), our findings show how group decisions can cross scale boundaries (i.e., the amount of resources that can be invested and their potential impact), scope boundaries (i.e., the purposes and "areas" that are appropriate), or both. In our cases, the groups crossed scale boundaries in terms of the resources they invested (finance rules) and investments' impact on industry (i.e., competition rules), and they crossed scope boundaries in terms of geography (i.e., geography rules) and industry (i.e., other scope rules). In breaking such rules, groups act to 
capture possible benefits (for themselves and/or others), thereby alleviating some of the tension associated with the focal decision.

Whether breaking scale or scope rules, those who break top management's decision-making rules run the risk of sanctions (MacLean, 2001; Siponen and Vance, 2010). Our findings highlight how groups that break top management's decision-making rules attempt to reduce the likelihood or minimize the extent of sanctions - that is, groups defend themselves. Groups can defend themselves by relying on postures that vary greatly in the extent to which they (i.e., the groups) take action to come into alignment with top management's decision-making rules. Some tactics attempt to hide from management's attention (i.e., ignoring) or redirect management's attention (i.e., blaming) to avoid sanctions for rule breaking. For other tactics, groups take some form of responsibility for their decision to reduce the extent of sanctions; that is, they confess and seek forgiveness or attempt to make amends. Finally, groups sometimes use correcting as a defense posture to avoid or minimize sanctions. By correcting, groups attempt to change top management's directives to bring the rules in line with the perceived benefits arising from their decision - that is, they attempt to remove the tension between the perceived benefits arising from their rule-breaking decision and the perceived costs of that decision (i.e., top-management sanctions). The point is that groups undertake defensive postures to avoid or minimize possible sanctions, and aside from the defensive posture that attempts to correct the situation by actively trying to change top management's rules, the goal of these postures is to minimize focus on or redirect attention from the focal decision.

\section{Sanctions, Decision-Making Rules, and Rule Breaking}

Our cases demonstrate that sanctions can be generated from within and outside organizations.

In the context of our study, group members felt that both forms of sanctions had considerable negative consequences for their group and for themselves personally. However, the objective nature of a negative event does not mean that a group will appraise it as highly threatening (Folkman, 2013; Folkman et al., 1986). Indeed, our analyses reveal that, through the use of defensive postures, groups anticipate whether they will be able to decrease the probability or severity of sanctions, thereby decreasing their appraisal of the threat associated with breaking the decision-making rules. These defensive postures work by either avoiding top management's attention or redirecting top management's attention away from groups' rule-breaking decisions. Therefore, when top 
management ineffectively monitors, detects, and/or punishes groups for rule breaking, they undermine the very reason for the sanctions - to stop rule breaking. Being ignorant of groups' breaking decisionmaking rules, top management is denied the opportunity to receive feedback that is important for adjusting the rules to capture the prosocial benefits of groups' decisions (if any) and/or align organizational and employee incentives.

Furthermore, groups' breaking of decision-making rules is likely reduced when top management increases groups' appraisal of the threat of sanctions and the incentives of group change (i.e., coming into greater alignment with top management), groups' defensive postures are rendered ineffective (and groups are sanctioned), and/or top management changes the decision-making rules (to be more consistent with groups' incentives). Absent these changes, groups are likely to continue breaking decision-making rules.

\section{DISCUSSION}

Prior research has investigated the importance of both group decision making (Forbes and Milliken, 1999; Petkova et al., 2014) and groups' rule breaking (Adler and Borys, 1996; Edwards and Wajcman, 2005; Sallaz, 2002). Through the current study, we add to these literatures by highlighting the mechanisms of rallying a group to break decision-making rules and defending the group from possible sanctions from top management. These highlighted mechanisms suggest that in addition to focusing on the decision to break rules, research should pay attention to the mechanisms underlying the "how" of these actions - that is, how group members are rallied to break decision-making rules and what postures groups take to defend themselves from sanctions that allow such rule breaking to persist.

We focused on government groups tasked with funding entrepreneurial ventures. Although these groups and funding decisions have some unique features, they reveal a chronology of activities that provide insights into the group nature of funding-related rule breaking: first, top management's decision-making rules are explicit and known; then, employees' interests (for themselves or others) trigger member rallying for the focal group to break the decision-making rules; and finally, the group engages particular postures to defend the group against sanctions. Thus, our findings indicate that rallying and defending the group - together with employees' interests in themselves (Griffin and Lopez, 2005; Renn et al., 2005; Robinson and Bennett, 1995; Vardaman et al., 2014), their 
organization (Anteby, 2008; Morrison, 2006), and others outside the organization - are critical aspects of rule-breaking decisions that require further exploration to provide a deeper understanding of how deviations in a group's decision making from top management's formal directives unfold.

Importantly, the current study's analyses and findings provide some insights into the issues and frustrations that often arise when top management expects employees to conform to rules. Although the literature has acknowledged the importance of rule following (e.g., Cooper, 1994; Nadkarni and Narayan, 2007) and has recognized that employees may have incentives for breaking rules (e.g., Gino and Pierce, 2010; Renn et al., 2005; Robinson and Bennett, 1995; Warren, 2003), we found that it is the tension between the two that triggers the rallying of group members to break top management's decision-making rules. That is, rule breaking involves a mental calculation of the pros and cons of rule following and the pros and cons of rule breaking, and the net benefits of one action vis-à-vis the other action can be the deciding factor.

Analyzing the tactics by which members of a group rally has the potential to advance crosslevel research on organizing more generally. Individuals form groups for decisions and actions unrelated to rule breaking. The mechanisms by which a group is formed are attributed to upper- and lower-level constructs. For example, leaders are instrumental in influencing members to work as a group (Lim and Ployhart, 2004; Yammarino, Dansereau, and Kennedy, 2001; e.g., charismatic leadership and persuasion [Lester, Meglino, and Korsgaard, 2002]), and members' social interactions (Klein et al., 2001) and communications (Lester et al., 2002; Wilson, Goodman, and Cronin, 2007) lead to a shared view (Kim et al., 2017) that regulates (Feldman, 1984) and coordinates (Astley and Fombrun, 1983) members as a group. As Mathieu and Chen (2011: 611) noted, "the prevailing logic in management research is that the larger context within which lower-level processes are nested generally exerts a greater downward influence than what lower level variables exert on the higher level context." In this study, we highlighted the specific types of interactions that lead to the bottomup rallying of members for group rule breaking in contravention of top-down decision-making directives. Therefore, our findings complement these group studies by making explicit the bottom-up rallying mechanisms by which members come together and the ways groups attempt to manage top management's assessments (via defensive mechanisms), both of which have important implications for the cycle of rule breaking by groups in their decision making.

This article is protected by copyright. All rights reserved 
Furthermore, the current study provides new insights into how funding decisions may deviate from what is expected based on espoused decision-making criteria. The decision-making perspective also offers insights into how a group is rallied and to what effect, especially the formation of group inuse decisions that deviate from espoused organizational decision policies (as represented by rules). The group perspective also provides insights into how groups espouse previous decisions as a means of defending themselves from an in-use decision policy that deviates from top management's decision policy. These findings provide new insights into the debate over in-use versus espoused decision making in general (Priem, 1992; Priem and Harrison, 1994) and funding decision making in particular (Shepherd, 1999; Zacharakis and Meyer, 1998) and may also contribute to the conversation about governments' allocation of public funds. We certainly hope that future research will build on the current study to increase our knowledge of the group and cross-level processes of allocating funds in government departments.

Although we focused on rule breaking in the investment decision-making context, our analyses and findings also add to management and strategic management research. The extant research in these areas has focused on top-down processes for directing employees and groups (Grant, 2003; Hoskisson and Hitt, 1988) but has also acknowledged that top management can have blind spots that contribute to organizational rigidity (Hodgkinson and Healey, 2011; Shepherd, McMullen, and Ocasio, 2017; Tripsas and Gavetti, 2000). We highlight one way in which top management can form blind spots-namely, maintaining top-down decision-making rules despite the need for change. Top management may be blind to both the prosocial motivations and deviations of groups and often remains blind as the result of perpetrators' effective defensive postures. This blindness robs top management the opportunity to formalize processes for creating this prosocial value (for organizations and/or stakeholders). Furthermore, top management may be blind to the self-interested motivations of employees (and may remain blind), which creates a disconnect between the incentives of organizations (as perceived by top management) and those of employees. By focusing on rallying tactics and defensive postures, our analyses highlight how management-employee disconnects can become a group-level phenomenon and persist over time.

Our theorizing on the rallying and defending of groups relates to the labor literature on social movements (Fantasia and Stepan-Norris, 2004). A social movement is a collective that emerges

This article is protected by copyright. All rights reserved 
proactively to express a grievance to a perceived social problem or emerges reactively to a threatened change in the way of life (King and Soule, 2017: 414). By combining this study's insights about the practices of rallying and defending groups with the social movement notion of micromobilization"the collective work individuals do on behalf of a social movement or a social movement organization to muster, ready, coordinate, use and reproduce material resources, labor, and ideas for the collective" (Hunt and Benford, 2004: 438) — future research can explore the formation and role of collective identity, solidarity, and commitment in collectively breaking decision-making rules. For example, activists (of social movements) frame identities to recruit participants (Polletta and Jasper, 2001). More research is needed to understand the practices used to recruit new members to adopt a collective identity that enables (or obstructs) the collective breaking of decision-making rules.

\section{Managerial Implications}

This study has a number of managerial implications. First, despite sanctions targeted at selfinterest, group members can rally for group rule breaking to make decisions that help others external to their organization. That is, assuming that groups' break rules to benefit themselves or their organization will likely obscure other triggers of rule breaking and will therefore lead to ineffective sanctions. Top management needs to become aware of organizational members' prosocial motivations toward others external to the organization and use these prosocial motivations in functional ways (i.e., provide avenues for prosocial behaviors as an alternate to prosocial rule breaking).

Second, although heavy sanctions for group rule breaking may reduce the occurrence of these decisions, it can also drive decision making underground (i.e., partially or fully hidden from the top management by defensive group behaviors). When group rule breaking remains hidden from top management, organizations are robbed the opportunity to adjust their decision-making rules. Organizations can provide a forum through which members can proactively challenge and change existing decision-making rules to counteract the development and use of defensive measures by members to hide or disguise this group rule breaking. That is, to promote organizational performance, top management needs to ensure not only that decision-making rules are followed but also that rules are adapted as the result of organizational learning to fit with changing environmental conditions. Therefore, top management can periodically ask organizational members - perhaps in their workgroups — to add, delete, and adjust the rules that govern their decision making.

This article is protected by copyright. All rights reserved 
Finally, on the one hand, rotating members to different groups will obstruct (or slow down) group rallying to break decision-making rules and/or perhaps pierce groups' defensive postures in hiding or disguising such rule breaking. On the other hand, perhaps organizations can take advantage of members' rallying capability to achieve functional group tasks.

\section{Limitations}

As with all studies, the current one has a number of limitations, which also serve as opportunities for future research. First, the group members gave us - the researchers - permission to access all documents and attend meetings in real time. Although the openness with which these members discussed and decided on rule breaking suggests otherwise, it is possible that they altered their written assessments and their opinions in meetings because of our presence. Second, we did not ask questions about member selection for the groups or about the initial team-formation process, so we did not have a good understanding of the creation of the groups' identities. Such identity creation could be a missing variable in understanding rule breaking, especially in terms of prosocial group rule breaking for the benefit of others outside the organization. Third, we based our analysis on behaviors and communications, but beyond these indicators, we did not capture members' beliefs or intentions going into the meetings. It is possible that there were instances when one member entered a meeting feeling strongly about funding a particular project in breach of the rules and instances when the majority of group members entered a meeting feeling strongly about funding a particular project in breach of the rules. Perhaps, these different starting points could lead to different rallying mechanisms. It is also possible that some groups had a stronger belief that they would be successful at rule breaking - collective rule-breaking self-efficacy - than other groups. Future research can explore these issues, which are likely most evident with greater heterogeneity (within and across teams) than investigated here. Finally, although we focused on the discussions (written and verbal) at meetings to rally members for group decision making, it is possible that group rule breaking might involve "implicit collusion" for rule breaking (i.e., a wink and a nod for everyone to come to agreement) without explicit efforts to rally members. Perhaps an experiment-based method might be able to determine the conditions under which there is explicit rallying of members and conditions under which there is a more implicit form of collusion for groups to break decision-making rules.

\section{CONCLUSION}

This article is protected by copyright. All rights reserved 
We conducted a qualitative study to elaborate theory on groups' breaking of decision-making rules, which required us to understand how members of groups rallied and defended their group decisions. As a result, it became apparent that a disconnect between top management's decisionmaking rules and employees' incentives triggered groups to break the rules and then defend themselves from top management's sanctions. Importantly, as we gain a deeper understanding of why employees decide not to follow top management's directives and how top management can be kept in the dark regarding such actions, we may also gain insight into the flipside - namely, rule following and, more importantly, changes to decision-making rules and thus adaptation. Change can come in the form of employee incentives, attention to group deviations, and rule changes. The big picture message is that groups' efforts to rally and defend themselves matter for organizations. The findings of the current study provide a new theoretical understanding of decision-making rules in managing organizations, an understanding that highlights some of the significant mechanisms in the formation and persistence of rule breaking, which in turn provides insights into the formal and informal aspects of organizing.

\section{NOTES}

1. The management literature largely assumes that non-compliance with decision-making rules (by organizational employees and groups) is detrimental to top management's organizing efforts (Olin and Wickenberg, 2001; see research on some prosocial rule breaking for an exception [e.g., Morrison, 2006]). For example, Perrow (1986) highlighted rules as the means by which organizations can minimize biased decision making.

2. Given that teams are characterized as "small groups of interdependent individuals who share responsibility and outcomes" (Hollenbeck, Beersma and Schouten, 2012: 82), we use the label "groups" to include "teams within organizations" (consistent with Cohen and Bailey, 1997; Guzzo and Shea, 1992; Huy et al., 2016).

\section{ACKNOWLEDGEMENTS}

The authors would like to thank John Prescott and three anonymous reviewers for their developmental comments on earlier versions of this manuscript. 


\section{REFERENCES}

Adler, P. S. and Borys, B. (1996). 'Two types of bureaucracy: Enabling and coercive'. Administrative Science Quarterly, 41, 61-89.

Astley, W. G. and Fombrun, C. J. (1983). 'Collective strategy: Social ecology of organizational environments'. Academy of Management Review, 8, 576-87.

Anteby, M. (2008). Moral gray zones: Side productions, identity, and regulation in an aeronautic plant. Princeton, NJ: Princeton University Press.

Ashkanasy, N. M. and Daus, C. S. (2002). 'Emotion in the workplace: The new challenge for managers'. Academy of Management Executive, 16, 76-86.

Bandura, A. (1999). 'Moral disengagement in the perpetration of inhumanities'. Personality and Social Psychology Review, 3, 193-209.

Bandura, A., Barbaranelli, C., Caprara, G .V. and Pastorelli, C. (1996). 'Mechanisms of moral disengagement in the exercise of moral agency'. Journal of Personality and Social Psychology, 71, 364-74.

Bettenhausen, K. L. and Murnighan, J. K. (1991). 'The development of an intragroup norm and the effects of interpersonal and structural challenges'. Administrative Science Quarterly, 36, 2035.

Bingham, C. B. and Eisenhardt, K. M. (2011). 'Rational heuristics: The 'simple rules' that strategists learn from process experience'. Strategic Management Journal, 32, 1437-64.

Blau, P. M. (1955). The Dynamics of Bureaucracy. Chicago, IL: University of Chicago Press.

Brannick, M. T. and Prince, C. (1997). 'An overview of team performance measurement'. In Brannick, M., Salas, E. and Prince, C. (Eds), Team performance assessment and measurement. Psychology Press, 15-28.

Brown, S. L. and Eisenhardt, K. M. (1997). 'The art of continuous change: Linking complexity theory and time-paced evolution in relentlessly shifting organizations'. Administrative Science Quarterly, 42, 1-34.

This article is protected by copyright. All rights reserved 
Busse, C., Kach, A. and Wagner, S. (2017). 'Boundary conditions: what they are, how to explore them, why we need them, and when to consider them'. Organizational Research Methods, 20, 574-609.

Chugh, D., Bazerman, M. H. and Banaji, M. R. (2005). 'Bounded ethicality as a psychological barrier to recognizing conflicts of interest'. In Moore, D. A., Cain, D. M., Loewenstein, G. and Bazerman, M. H. (Eds). Conflicts of interest: Challenges and solutions in business, law, medicine, and public policy. New York: Cambridge University Press, 74-95.

Cialdini, R. B. and Trost, M. R. (1998). 'Social influence: Social norms, conformity, and compliance'. In Gilbert, D. T., Fiske, S. T. and Lindzey, G. (Eds), The handbook of social psychology, Vol. 2, $4^{\text {th }}$ Edition. Boston, MA: McGraw-Hill, 151-92.

Cohen, S. G. and Bailey, D. E. (1997). 'What makes teams work: Group effectiveness research from the shop floor to the executive suite'. Journal of Management, 23, 239-90.

Colbert, A. E., Mount, M. K., Harter, J. K., Witt, L. A. and Barrick, M, R. (2004). 'Interactive effects of personality and perceptions of the work situation on workplace deviance'. Journal of Applied Psychology, 89, 599-609.

Cooper, R. G. (1994). 'Perspective third-generation new product processes'. Journal of Product Innovation Management, 11, 3-14.

Cordery, J. L., Mueller, W. S. and Smith, L. M. (1991). 'Attitudinal and behavioral effects of autonomous group working: A longitudinal field study'. Academy of Management Journal, 34, 464-76.

Cyert, R. M. and March, J. G. (1963). 'A behavioral theory of the firm. Cambridge, MA: Blackwell.

Dahling, J. J., Chau, S. L., Mayer, D. M. and Gregory, J. B. (2012). 'Breaking rules for the right reasons? An investigation of pro-social rule breaking'. Journal of Organizational Behavior, 33, 21-42.

Davis, J. H., Laughlin, P. R. and Komorita, S. S. (1976). 'The social psychology of small groups: Cooperative and mixed-motive interaction'. Annual review of Psychology, 27, 501-41.

This article is protected by copyright. All rights reserved 
Desai, V. (2010). 'Rule violations and organizational search: A review and extension'. International Journal of Management Reviews, 12, 184-200.

Desmond, M. (2007). On the Fireline. Chicago, IL: University of Chicago Press.

Detert, J. R., Treviño, L. K. and Sweitzer, V. L. (2008). 'Moral disengagement in ethical decision making: A study of antecedents and outcomes'. Journal of Applied Psychology, 93, 374-91.

Dilchert, S., Ones, D. S., Davis, R. D. and Rostow, C. D. (2007). 'Cognitive ability predicts objectively measured counterproductive work behaviors'. Journal of Applied Psychology, 92, 616-27.

Dobbins, F. (2009). Inventing equal opportunity. Princeton, NJ: Princeton University Press.

Editorial board Houston Chronicle (2019). 'Did Astros break the rules?'. Houston Chronicle,

November 20. https://www.houstonchronicle.com/opinion/editorials/article/Did-Astros-breakthe-rules-Editorial-14847478.php

Edwards, P. and Wajcman, J. (2005). The politics of working life. Oxford University Press.

Ehrhart, M. G. and Naumann, S. E. (2004). 'Organizational citizenship behavior in work groups: a group norms approach'. Journal of Applied Psychology, 89, 960-74.

Epley, N. and Caruso, E. M. (2004). 'Egocentric ethics'. Social Justice Research, 17, 171-87.

Fantasia, R. and Stepan-Norris, J. (2004). 'The labor movement in motion'. In Snow, D. A., Soule, S. A. and Kriesi, H. (Eds) The Blackwell companion to social movements, 555-75.

Faraj, S. and Xiao, Y. (2006). 'Coordination in fast-response organizations'. Management Science, 52, 1155-69.

Feldman, D. C. (1984). 'The development and enforcement of group norms'. Academy of Management Review, 9, 47-53.

Folkman, S. (2013). Stress: Appraisal and coping. New York: Springer.

Folkman, S., Lazarus, R. S., Dunkel-Schetter, C., DeLongis, A. and Gruen, R. J. (1986). 'Dynamics of a stressful encounter: Cognitive appraisal, coping, and encounter outcomes'. Journal of Personality and Social Psychology, 50, 992-1003.

This article is protected by copyright. All rights reserved 
Forbes, D. P. and Milliken, F. J. (1999). 'Cognition and corporate governance: Understanding boards of directors as strategic decision-making groups'. Academy of Management Review, 24, 489505.

Fox, S., Spector, P. E. and Miles, D. (2001). 'Counterproductive work behavior. (CWB) in response to job stressors and organizational justice: Some mediator and moderator tests for autonomy and emotions'. Journal of Vocational Behavior, 59, 291-309.

Gavetti, G. and Levinthal, D. (2000). 'Looking forward and looking backward: Cognitive and experiential search'. Administrative Science Quarterly, 45, 113-37.

Gavetti, G., Levinthal, D. and Ocasio, W. (2007). 'Perspective-Neo-Carnegie: The Carnegie school's past, present, and reconstructing for the future'. Organization Science, 18, 523-36.

Giacalone, R. and Greenberg, J. (1997). Antisocial Behavior in Organizations. Thousand Oaks, CA: Sage.

Gibson, C. B. and Earley, P. C. (2007). 'Collective cognition in action: Accumulation, interaction, examination, and accommodation in the development and operation of group efficacy beliefs in the workplace'. Academy of Management Review, 32, 438-58.

Gino, F. and Pierce, L. (2010). 'Lying to level the playing field: Why people may dishonestly help or hurt others to create equity'. Journal of Business Ethics, 95, 89-103.

Gino, F. and Wiltermuth, S. S. (2014). 'Evil genius? How dishonesty can lead to greater creativity'. Psychological Science, 25, 973-81.

Gioia, D. A., Corley, K. G. and Hamilton, A. L. (2013). 'Seeking qualitative rigor in inductive research: Notes on the Gioia methodology'. Organizational Research Methods, 16, 15-31.

Gladstein, D. L. (1984). 'Groups in context: A model of task group effectiveness'. Administrative Science Quarterly, 29, 499-517.

Gouldner, A. W. (1954). Patterns of industrial bureaucracy. New York: Free Press.

Grant, R. M. (2003). 'Strategic planning in a turbulent environment: Evidence from the oil majors'. Strategic Management Journal, 24, 491-517.

This article is protected by copyright. All rights reserved 
Griffin, R. W. and Lopez, Y. P. (2005). 'Bad behavior in organizations: A review and typology for future research'. Journal of Management, 31, 988-1005.

Guzzo, R. A. and Shea, G. P. (1992). 'Group performance and intergroup relations in organizations'. In Dunnette, M. D. and Hough, L. M. (Eds), Handbook of industrial and organizational psychology. Palo Alto, CA: Consulting Psychologists Press, 269-313.

Hale, A. and Borys, D. (2013). 'Working to rule, or working safely? Part 1: A state of the art review'. Safety Science, 55, 207-21.

Hodgkinson, G. P. and Healey, M. P. (2011). 'Psychological foundations of dynamic capabilities: reflexion and reflection in strategic management'. Strategic Management Journal, 32, 150016.

Hollenbeck, J. R, Beersma, B. and Schouten, M. E. (2012). 'Beyond team types and taxonomies: A dimensional scaling conceptualization for team description'. Academy of Management Review, 37, 82-106.

Hoskisson, R. E. and Hitt, M. A. (1988). 'Strategic control systems and relative R\&D investment in large multiproduct firms'. Strategic Management Journal, 9, 605-21.

Hunt, S. A. and Benford, R. D. (2004). 'Collective identity, solidarity, and commitment'. In Snow, D. A. Soule, S. A. and Kriesi, H. (eds) The Blackwell companion to social movements, 433-57.

Huy, Q. N., Sonenshein, S. and Bresman, H. (2016). 'Leading strategic change under uncertainty'. Academy of Management Proceedings, 1, 11518.

Jetten, J. and Hornsey, M. J. (2014). 'Deviance and dissent in groups'. Annual Review of Psychology, 65, 461-85.

Joshi, A. and Roh, H. (2009). 'The role of context in work team diversity research: A meta-analytic review'. Academy of Management Journal, 52, 599-627.

Judge, T. A, Scott, B. A. and Ilies, R. (2006). 'Hostility, job attitudes, and workplace deviance: test of a multilevel model'. Journal of Applied Psychology, 91, 126-38.

This article is protected by copyright. All rights reserved 
Kim, A., Kim, Y., Han, K., Jackson, S. E. and Ployhart, R. E. (2017). 'Multilevel influences on voluntary workplace green behavior: Individual differences, leader behavior, and coworker advocacy'. Journal of Management, 43, 1335-58.

King, B. G. and Soule, S. A. (2007). 'Social movements as extra-institutional entrepreneurs: The effect of protests on stock price returns'. Administrative Science Quarterly, 52, 413-42.

Klein, K. J., Conn, A. B., Smith, D. B. and Sorra, J. S. (2001). 'Is everyone in agreement? An exploration of within-group agreement in employee perceptions of the work environment'. Journal of Applied Psychology, 86, 3-16.

Klein, K. J., Dansereau, F. and Hall, R. J. (1994). 'Levels issues in theory development, data collection, and analysis'. Academy of Management Review, 19, 195-229.

Kraut, R. E. and Streeter, L. A. (1995). 'Coordination in software development'. Communications of the $A C M, \mathbf{3 8}, 69-82$.

Langley, A. (1999). 'Strategies for theorizing from process data'. Academy of Management Review, 24, 691-710.

Lehman, D. W. and Ramanujam, R. (2009). 'Selectivity in organizational rule violations'. Academy of Management Review, 34, 643-57.

Lester, S. W., Meglino, B. M. and Korsgaard, M. A. (2002). 'The antecedents and consequences of group potency: A longitudinal investigation of newly formed work groups'. Academy of Management Journal, 45, 352-68.

Lim, B. C. and Ployhart, R. E. (2004). 'Transformational leadership: relations to the five-factor model and team performance in typical and maximum contexts'. Journal of Applied Psychology, 89, $610-21$.

Lincoln S. Y. and Guba, E. G. (1985). Naturalistic Inquiry. Thousand Oaks, CA: Sage.

Locke, K. (1996). 'Rewriting the discovery of grounded theory after 25 years?'. Journal of Management Inquiry, 5, 239-45.

This article is protected by copyright. All rights reserved 
Lovelace, K., Shapiro, D. L. and Weingart, L. R. (2001). 'Maximizing cross-functional new product teams' innovativeness and constraint adherence: A conflict communications perspective'. Academy of Management Journal, 44, 779-93.

MacLean, T. L. (2001). 'Thick as thieves: A social embeddedness model of rule breaking in organizations'. Business Society, 40, 167-96.

Manz, C. C. and Sims Jr, H. P. (1987). 'Leading workers to lead themselves: The external leadership of self-managing work teams'. Administrative Science Quarterly, 32, 106-29.

March, J. G. (1997). 'Administrative practice, organization theory, and political philosophy: Ruminations on the reflections of John M. Gaus'. PS: Political Science Politics, 30, 689-98.

March, J. G., Schulz, M. and Zhou, X. (2000). The dynamics of rules. Stanford, CA: Stanford Press.

March, J. G. and Simon, H. A. (1958). Organizations. Oxford: Wiley.

Martin, S. R., Kish-Gephart, J. J. and Detert, J. R. (2014). 'Blind forces: Ethical infrastructures and moral disengagement in organizations'. Organizational Psychology Review, 4, 295-325.

Martin, A. W., Lopez, S. H., Roscigno, V. J. and Hodson, R. (2013). 'Against the rules: Synthesizing types and processes of bureaucratic rule-breaking'. Academy of Management Review, 38, 55074.

Mathieu, J. E. and Chen, G. (2011). 'The etiology of the multilevel paradigm in management research'. Journal of Management, 37, 610-41.

McGrath, R. G. (1999). 'Falling forward: Real options reasoning and entrepreneurial failure'. Academy of Management Review, 24, 13-30.

McGrath, J. E. and Argote, L. (2001). 'Group processes in organizational contexts'. In Hogg, M. A. and Tindale, R. S. (Eds), Blackwell handbook of social psychology: Group processes. Oxford: Blackwell Publishers Ltd, 603-27.

Monin, P., Noorderhaven, N., Vaara, E. and Kroon, D. (2013). 'Giving sense to and making sense of justice in postmerger integration'. Academy of Management Journal, 56, 256-84.

This article is protected by copyright. All rights reserved 
Morrison, E. W. (2006). 'Doing the job well: An investigation of pro-social rule breaking'. Journal of Management, 32, 5-28.

Nadkarni, S. and Narayanan, V. K. (2007). 'Strategic schemas, strategic flexibility, and firm performance: The moderating role of industry clockspeed'. Strategic Management Journal, 28, 243-70.

Ocasio, W. (2011). 'Attention to attention'. Organization Science, 22, 1286-96.

Ocasio, W. (1997). 'Towards an attention-based view of the firm'. Strategic Management Journal, 18, 187-206.

Okhuysen, G. A. and Bechky, B. A. (2009). 'Coordination in organizations: an integrative perspective'. Academy of Management Annals, 3, 463-502.

Olin, T. and Wickenberg, J. (2001). 'Rule breaking in new product development: Crime or necessity?'. Creativity and Innovation Management, 10, 15-25.

Ouchi, W. (1980). 'Markets, bureaucracies, and clans'. Administrative Science Quarterly, 25, 129-41.

Perrow, C. (1986). 'Economic theories of organization'. Theory and Society, 15, 11-45.

Petkova, A. P., Wadhwa, A., Yao, X. and Jain, S. (2014). 'Reputation and decision making under ambiguity: a study of US venture capital firms' investments in the emerging clean energy sector'. Academy of Management Journal, 57, 422-48.

Polletta, F. and Jasper, J. M. (2001). 'Collective identity and social movements'. Annual Review of Sociology, 27, 283-305.

Pratt, M. G. (2009). 'From the editors: For the lack of a boilerplate: Tips on writing up (and reviewing) qualitative research'. Academy of Management Journal, 52, 856-62.

Priem, R. L. (1992). 'An application of metric conjoint analysis for the evaluation of top managers' individual strategic decision making processes: a research note'. Strategic Management Journal, 13, 143-51.

Priem, R. L. and Harrison, D. A. (1994). 'Exploring strategic judgment: Methods for testing the assumptions of prescriptive contingency theories'. Strategic Management Journal, 15, 311-24.

This article is protected by copyright. All rights reserved 
Renn, R. W., Allen, D. G., Fedor, D. B. and Davis, W. D. (2005). 'The roles of personality and selfdefeating behaviors in self-management failure'. Journal of Management, 31, 659-79.

Rico, R., Sánchez-Manzanares, M., Gil, F. and Gibson, C. (2008). ‘Team implicit coordination processes: A team knowledge-based approach'. Academy of Management Review, 33, 163-84.

Robinson, S. L. and Bennett, R. J. (1995). 'A typology of deviant workplace behaviors: A multidimensional scaling study'. Academy of Management Journal, 38, 555-72.

Sallaz, J. (2009). The labor of luck: Casino capitalism in the United States and South Africa. Los Angeles, CA: University of California Press.

Sallaz, J. J. (2002). 'The house rules: Autonomy and interests among service workers in the contemporary casino industry'. Work and Occupations, 29, 394-427.

Shepherd, D. A. (1999). 'Venture capitalists' assessment of new venture survival'. Management Science, 45, 621-32.

Shepherd, D. A., McMullen, J. S. and Ocasio, W. (2017). 'Is that an opportunity? An attention model of top managers' opportunity beliefs for strategic action'. Strategic Management Journal, 38, $626-44$.

Shepherd, D. A., Patzelt, H. and Baron, R. A. (2013). “'I care about nature, but...”: Disengaging values in assessing opportunities that cause harm'. Academy of Management Journal, 56, 1251-73.

Shu, L. L., Gino, F. and Bazerman, M. H. (2011). 'Dishonest deed, clear conscience: When cheating leads to moral disengagement and motivated forgetting'. Personality and Social Psychology Bulletin, 37, 330-49.

Simon, H. A. (1947). Administrative Behavior: A Study of Decision-Making Processes in Administrative Organization. New York: Macmillan.

Siponen, M. and Vance, A. (2010). 'Neutralization: new insights into the problem of employee information systems security policy violations'. MIS Quarterly, 34, 487-502.

This article is protected by copyright. All rights reserved 
Tannenbaum, S. I., Beard, R. L. and Salas, E. (1992). 'Team building and its influence on team effectiveness: An examination of conceptual and empirical developments'. Advances in Psychology, 82, 117-53.

Tindale, R. S. and Winget, J. R. (2019). 'Group decision-making'. In Oxford Research Encyclopedia of Psychology.

Tripsas, M. and Gavetti, G. (2000). 'Capabilities, cognition, and inertia: Evidence from digital imaging'. Strategic Management Journal, 21, 1147-61.

Tversky, A. and Kahneman, D. (1973). 'Availability: A heuristic for judging frequency and probability'. Cognitive Psychology, 5, 207-32.

Twenge, J. M., Catanese, K. R. and Baumeister R. F. (2003). 'Social exclusion and the deconstructed state: Time perception, meaninglessness, lethargy, lack of emotion, and self-awareness'. Journal of Personality and Social Psychology, 85, 409-23.

Tyler, T. R. and Blader, S. L. (2005). 'Can businesses effectively regulate employee conduct? The antecedents of rule following in work settings'. Academy of Management Journal, 48, 114358.

Van de Ven, A. H., Delbecq, A. L. and Koenig Jr, R. (1976). 'Determinants of coordination modes within organizations'. American Sociological Review, 41, 322-38.

Vardaman, J. M., Gondo, M. B. and Allen, D. G. (2014). 'Ethical climate and pro-social rule breaking in the workplace'. Human Resource Management Review, 24, 108-18.

Vardi, Y. and Weitz, E. (2004). Misbehavior in Organizations: Theory, Research, and Management. Mahwah, NJ: Lawrence Erlbaum.

Vaughan, D. (1990). 'Autonomy, interdependence, and social control: NASA and the space shuttle Challenger'. Administrative Science Quarterly, 35, 225-57.

Warren, D. E. (2003). 'Constructive and destructive deviance in organizations'. Academy of Management Review, 28, 622-32.

This article is protected by copyright. All rights reserved 
Wilson, J. M., Goodman, P. S. and Cronin, M. A. (2007). 'Group learning'. Academy of Management Review, 32, 1041-59.

Yammarino, F. J., Dansereau, F. and Kennedy, C. J. (2001). 'A multiple-level multidimensional approach to leadership: Viewing leadership through an elephant's eye'. Organizational Dynamics, 29, 149-49.

Zacharakis, A. L. and Meyer, G. D. (1998). 'A lack of insight: Do venture capitalists really understand their own decision process?'. Journal of Business Venturing, 13, 57-76.

This article is protected by copyright. All rights reserved 
Figure 1: Data Structure

\section{First-Order Categories \\ Second-Order Themes \\ Aggregate Dimensions}

- Do not finance ventures with production in another region.

- Do not finance ventures with headquarters outside the region.

- Do not finance ventures with ownership outside the region.

- Do not finance ventures with solvency that is too high.

- Do not finance ventures owners who have payment defaults.

- Do not finance investments in ventures at risk of bankruptcy.

- Do not finance ventures with regional competitors.

- Do not finance ventures risking distortive market effects.

- Do not finance ventures providing competitive advantage in frout of competitors.

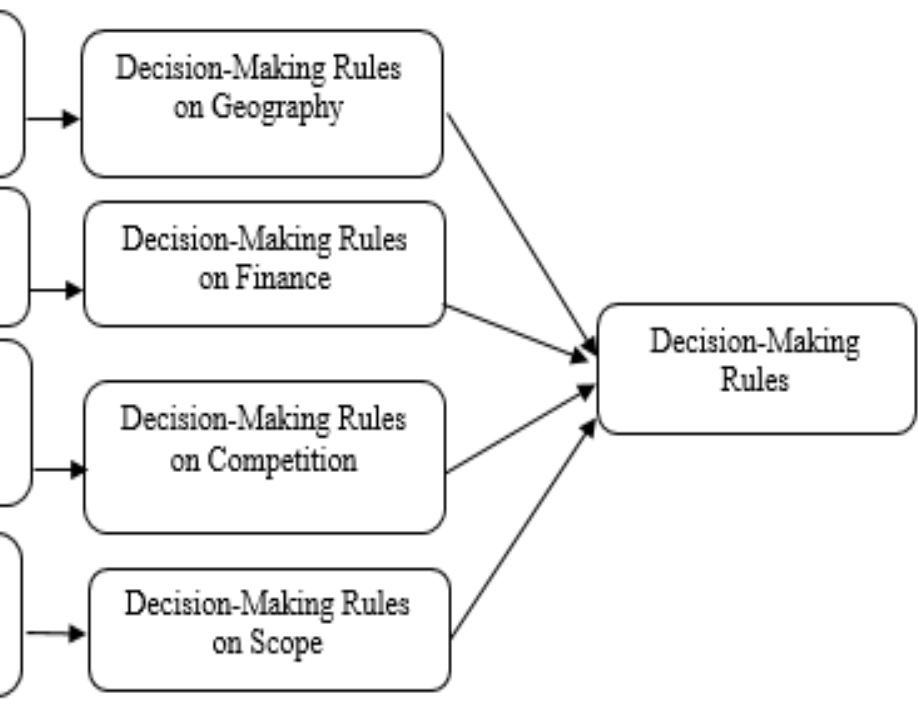

Do not finance vehicles

- Do not finance movable machines, equipment; no fixed assets.

- Do not finance contracting businesses.

$$
\text { on Scope }
$$

The financiers feel kind when providing finance.

- The financiers feel pity for the entrepreneur.

- The financiers love the venture's service product.

- Other financiers would also tum down the proposal.

- The entrepreneur needs belp to reach a dream.

- Finance is for a good cause-an upcoming venture.

- For the region's best interest-the venture expects to contribute to the region.

- For the enviroument, for decreaging pollution.

- Other regional businesses benefit from investments in the venture-powerful businesses in the region require investments in the venture.

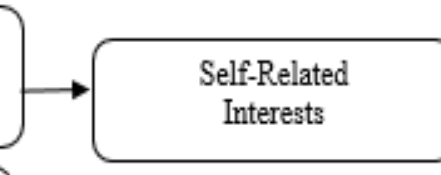

1.

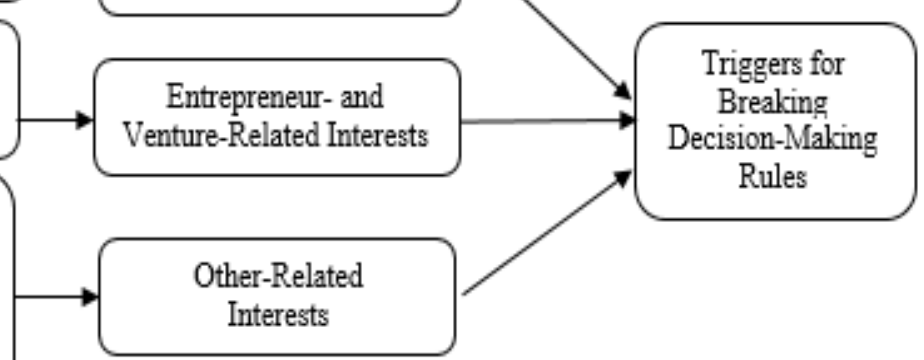

- Using broader interpretations for higher flexibility.

- Offering hypotheticals (despite low probability).

- Rename investments to fit. Service instead of a traditional production line; upgrading instead of renovation.

- Reading between the lines.

- Use carrots rather than whips.

- The new criteria are not yet there, but it is vital.

- Adjustment of rules to the new gituation-a new era with new problems to be solved.

- Out of control for the financiers; complexity is too high.

- It all happened too fast, glipping through.

- We have always done it like this.

- This has become a norm in our group.

- We accepted it the last time; let's continue in the same way.

- Unique venture: they are not like others.

- Unique situation: once in a lifetime.

- Unique innovative products: not traditional.
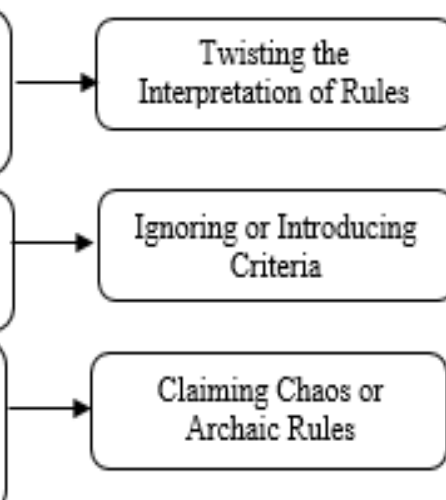

Making Selective

Historical Claims

Exceptionalizing

Tactics for

Rallying the

Group

This article is protected by copyright. All rights reserved 


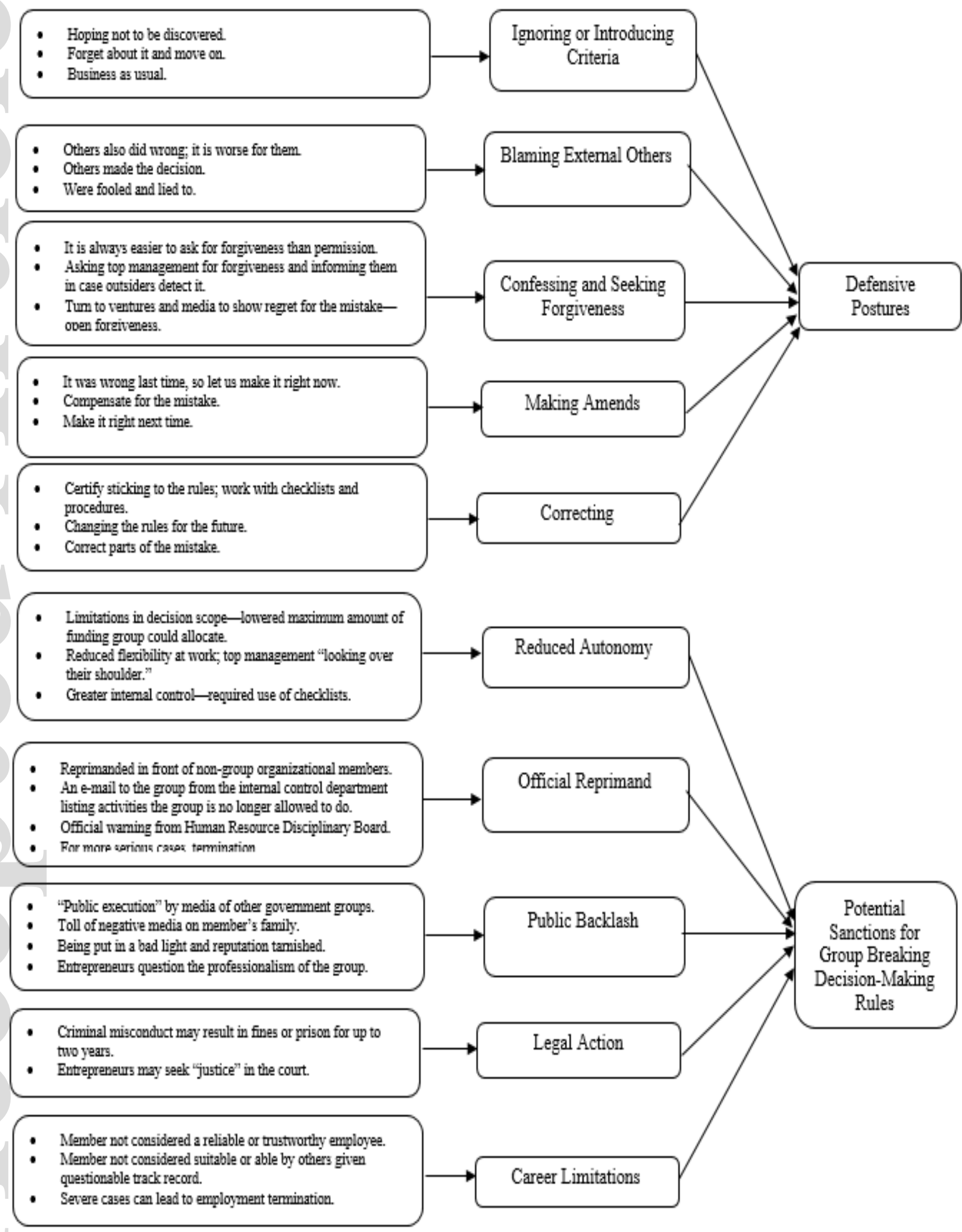

This article is protected by copyright. All rights reserved 
Figure 2a: Pathways of Groups Breaking Decision-Making Rules to Benefit the Group*

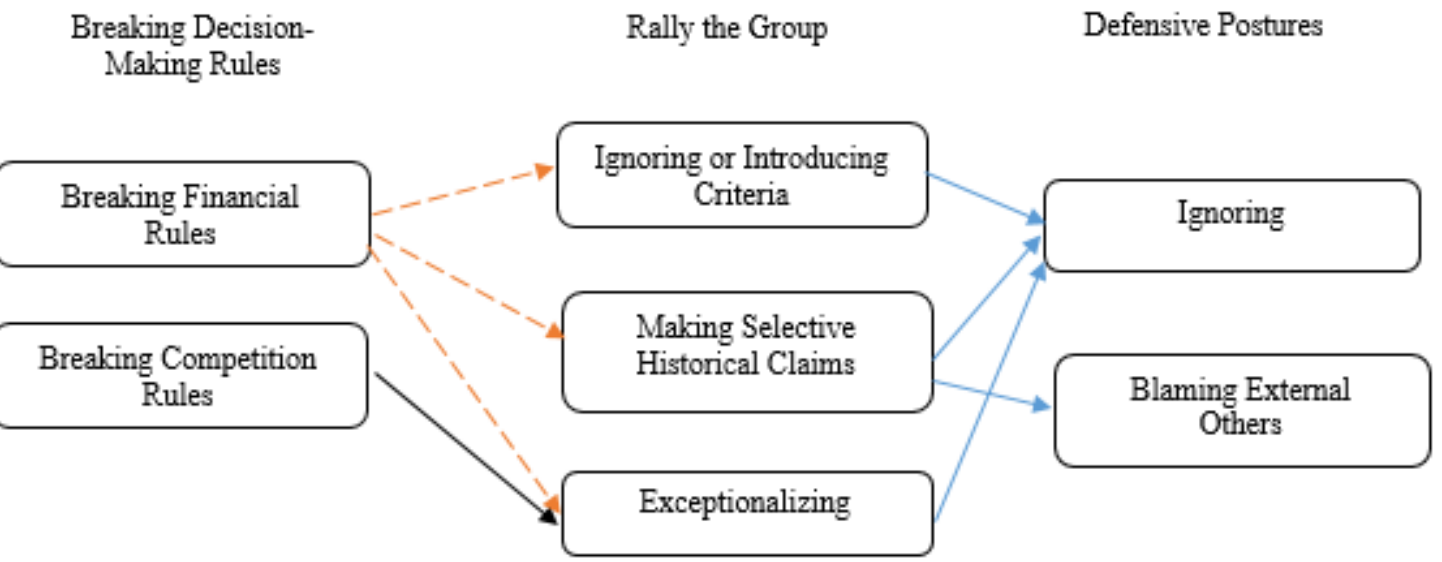

Figure 2b: Pathways of Groups Breaking Decision-Making Rules to Benefit Entrepreneur

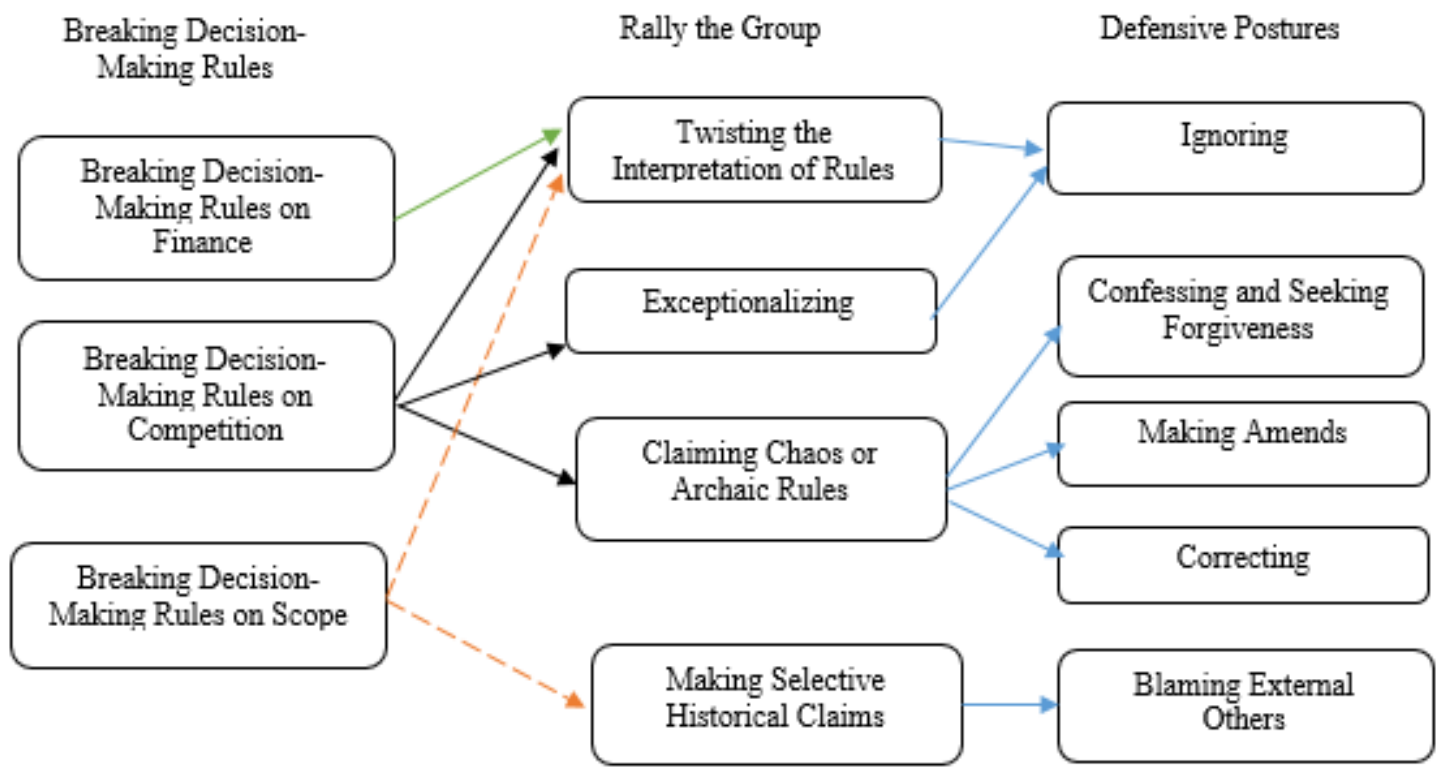

- The differences in the arrows reflect their origin.

This article is protected by copyright. All rights reserved 
Figure 2c: Pathways of Groups Breaking Decision-Making Rules to Benefit Others

Breaking Decision-
Making Rules

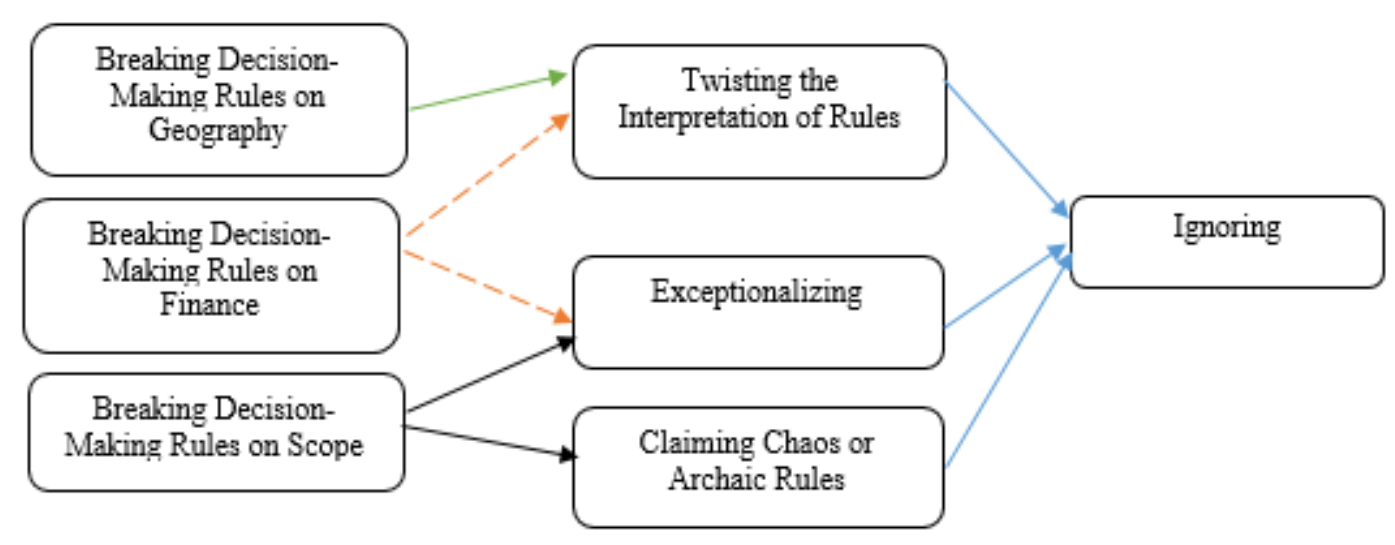

This article is protected by copyright. All rights reserved 
Figure 3: A Grounded Model of Groups Breaking Decision-Making Rules

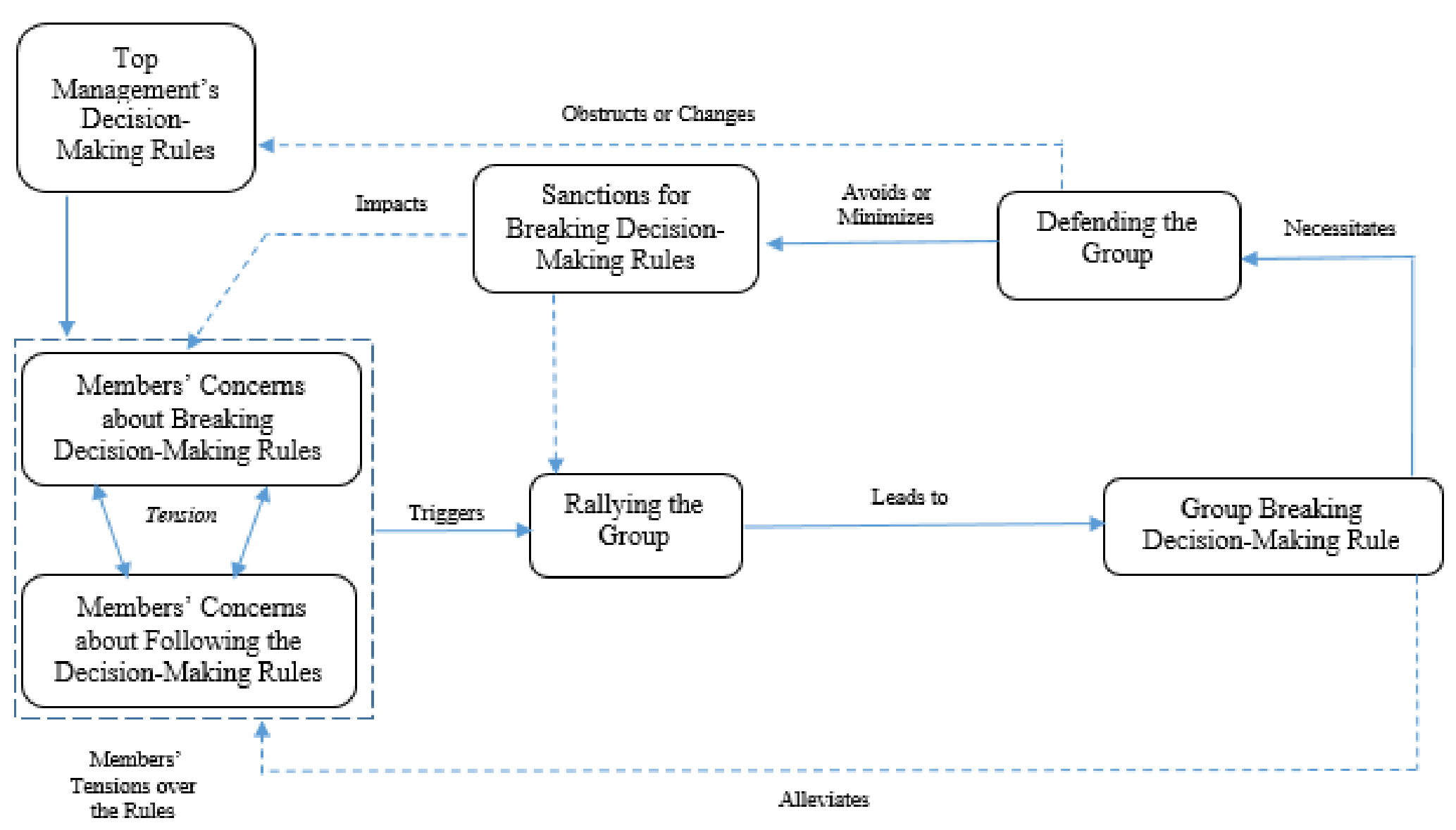

This article is protected by copyright. All rights reserved 
Figure 4: Tensions in a Group Breaking Decision-Making Rules

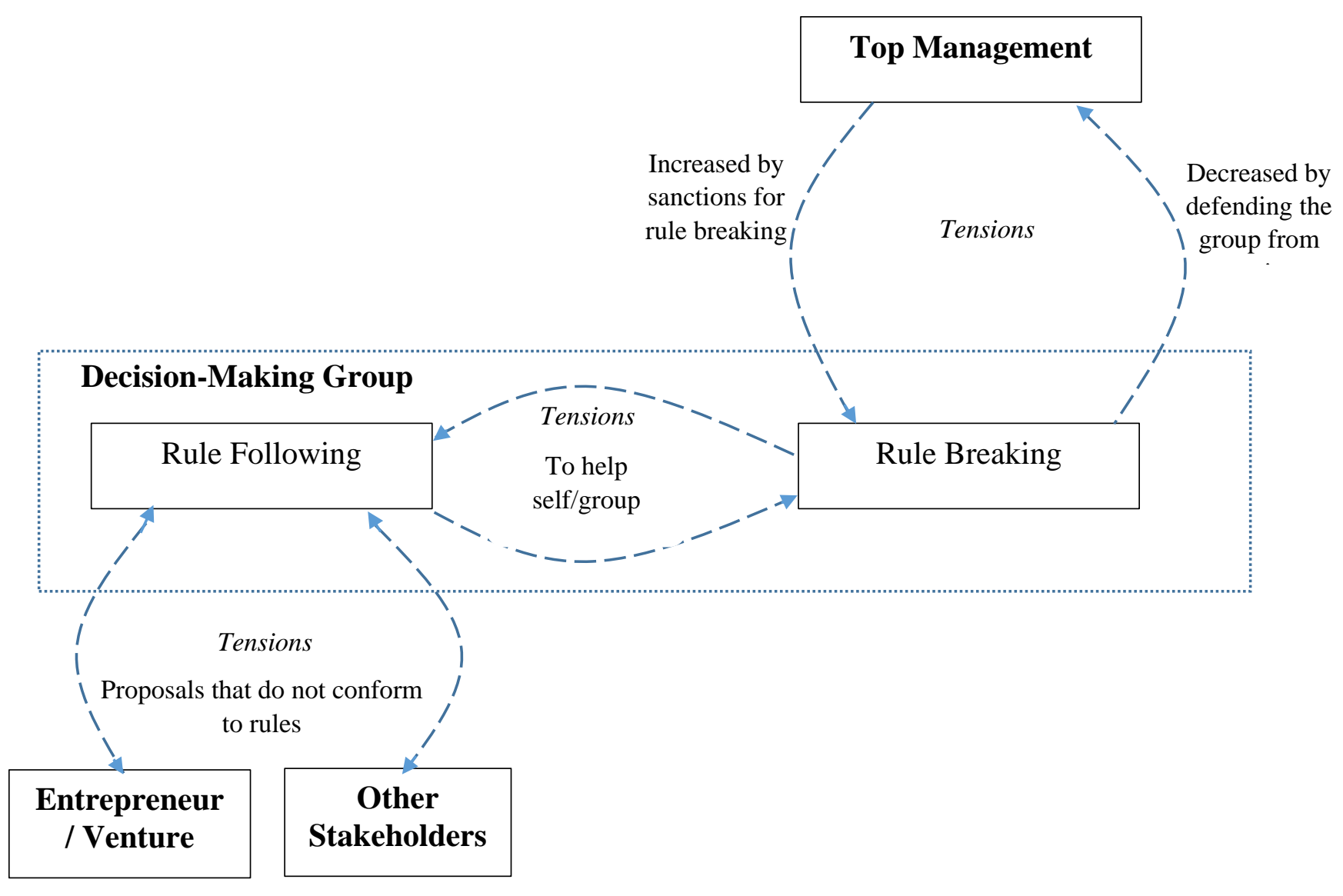


Table 1: Quantitative Details on Observation and Interview Data

\begin{tabular}{|l|l|l|l|l|l|}
\hline & Alpha & Bravo & Charlie & Delta & Echo \\
\hline $\begin{array}{l}\text { Members of the } \\
\text { Group }\end{array}$ & $\begin{array}{l}\text { Albert, Alva, } \\
\text { Anton, Anna, } \\
\text { Axel }\end{array}$ & $\begin{array}{l}\text { Bodil, Bo, Britt, } \\
\text { Bert, Birgita, } \\
\text { Bengt }\end{array}$ & $\begin{array}{l}\text { Carl, Cecilia, } \\
\text { Claes }\end{array}$ & $\begin{array}{l}\text { Dagny, David, } \\
\text { Doris }\end{array}$ & Einar, Eva \\
\hline Chair & Albert & Bo & Carl & Dagny & Eva \\
\hline $\begin{array}{l}\text { Number of } \\
\text { Investments } \\
\text { Annually }\end{array}$ & 151 & 202 & 104 & 26 & 141 \\
\hline $\begin{array}{l}\text { Number of } \\
\text { Investments in } \\
\text { This Study }\end{array}$ & 45 & 41 & 32 & 24 & 27 \\
\hline $\begin{array}{l}\text { Skill } \\
\text { Differentiation }\end{array}$ & Homogenous & Homogenous & Homogenous & Homogenous & Homogenous \\
\hline $\begin{array}{l}\text { Authority } \\
\text { Differentiation }\end{array}$ & $\begin{array}{l}\text { Consensus } \\
\text { driven }\end{array}$ & $\begin{array}{l}\text { Consensus } \\
\text { driven }\end{array}$ & $\begin{array}{l}\text { Consensus } \\
\text { driven }\end{array}$ & $\begin{array}{l}\text { Consensus } \\
\text { driven }\end{array}$ & $\begin{array}{l}\text { Consensus } \\
\text { driven }\end{array}$ \\
\hline $\begin{array}{l}\text { Temporal } \\
\text { stability }\end{array}$ & $\begin{array}{l}\text { Stable (Mean } \\
\text { tenure }=12)\end{array}$ & $\begin{array}{l}\text { Stable (Mean } \\
\text { tenure }=15)\end{array}$ & $\begin{array}{l}\text { Stable (Mean } \\
\text { tenure = 10) }\end{array}$ & $\begin{array}{l}\text { Stable (Mean } \\
\text { tenure }=20)\end{array}$ & $\begin{array}{l}\text { Stable (Mean } \\
\text { tenure }=21)\end{array}$ \\
\hline $\begin{array}{l}\text { Total } \\
\text { Investment SK } \\
\text { (USD) }\end{array}$ & $\begin{array}{l}15,600,000 \\
(1,740,000)\end{array}$ & $\begin{array}{l}7,200,000 \\
(803,000)\end{array}$ & $\begin{array}{l}10,300,000 \\
(1,150,000)\end{array}$ & $\begin{array}{l}4,970,000 \\
(555,000)\end{array}$ & $\begin{array}{l}16,000,000 \\
(1,785,000)\end{array}$ \\
\hline
\end{tabular}

Table 2: Details of Data Sources

\begin{tabular}{|l|l|}
\hline Source/Audience & No. \\
\hline Proposals from entrepreneurial ventures (1,000 pages) & 169 \\
\hline Governmental regulations & 1 \\
\hline Governmental financiers checklists & 1 \\
\hline Governmental financiers webpages & 5 \\
\hline Governmental financiers annual reports & 5 \\
\hline Agenda for investment discussion meetings & 15 \\
\hline Field notes by researchers (120 pages) & 15 \\
\hline Interview transcriptions of observations (552 pages) & 15 \\
\hline Total Number of Sources & $\mathbf{2 2 6}$ \\
\hline
\end{tabular}

This article is protected by copyright. All rights reserved 
Table 3: Tactics for Rallying the Group Twisting Interpretation of the Rules: Exemplary Quotes

"They invested in a machine recently. They are out on the roads with the machine but we agreed that it is only a minor part of the time. They mainly work at home. .. We stretch our decision somewhat, that's ok."

"They offer a fantastic product but it's clearly traditional construction. Out of scope for us. Nevertheless, we can see it as distribution of a service instead of as a traditional physical production line, which gives us higher freedom in our decision. Let's do it."

"To be crass, an inventory should be in the venture's inventory list, be part of the balance sheet and be depreciated between one and five years." "Yes, that's right." "So to be honest, that's the rule." "Yea, that's incredibly too narrow, but we can go beyond that and accept some finance. ...." "Then, it's ok." "Yes, it is in the startup-phase." "We provide a limited scope of finance."

Ignoring or Introducing Criteria: Exemplary Quotes

"We are not allowed to finance the sale of organizations." "Why not just ignore that criterion. There are so many criteria, we can't apply them all. This criterion is not that important." "The rest of the investment sounds ok."

"We are not allowed to finance this type of machinery but we have made our own interpretation and decided to have a rule of our own for this type of machinery." "Yes, we want the machinery to be more environmental friendly." "We want them to become more environmental friendly." This is a new criterion to be used."

"The machine is so big, so it's not possible to move it even though it is not fixed as it must be for accessing finance. We know that they can move it, there is equipment for that but we use size as a criteria, and it's still a bit hard to move."

Claiming Chaos or Archaic Rules: Exemplary Quotes

"Why finance them, it's not in line with what we should finance?" "They call you and you want to treat them well and you make a decision too fast. That's not often but it happens. I made a promise in a chaotic situation and we have to keep that promise. "Ok, we understand the situation." "It all happened so fast it was out of our control."

"This decision is a mistake, we should not have accepted it but it slipped through." "We do not have resources. We are out of people and this is a difficult situation. People are sick, retiring and so on." "Yea, there are so many applications ahead, a long list to be considered and we can hardly deal with it." "Such things happens, let's move forward."

"The problem is that there are so many industries to assess and deal with. We do not have the right competence for this decision. We cannot have the same competence in all industries. We cannot know it all." "It is difficult to determine." "The regulation is also "messy", it is not clear at all." "However, it will not look good from an evaluator's point of view, but there is nothing we can do about it." "We try to do our best in this chaotic situation."

\section{Making Selective Historical Claims: Exemplary Quotes}

"Financing entrepreneurs' private investments is out of our scope." "Though, we have financed the restoration of a house before and need to continue to contribute when they are about to start the business." "We accepted it last time." "They received finance before so we need to provide additional finance so they can keep up with the development." "It was in the grey zone then. We can't let them down."

"The problem is that there is no production in the company and we can only provide support to producing companies." "We had a discussion earlier and came to a similar decision, to finance even though the investment actually is out of scope." "Yea, we have financed other similar companies in the same situation before, companies that not are producing." "Ok, let's continue in the same way".

"We decide yes. It's a bit out of scope for what we are supposed to finance but maybe a change in rules are about to take place. I think so." "There may come some corrections in the regulation that may make it work. We are a bit early but the change will take place sooner or later"

\section{Exceptionalizing: Exemplary Quotes}

"We are not allowed to support reinvestments according to the regulation." "There are mitigating circumstances in this case." "We can define it as an upgrading instead, which is ok to support." "Yes, we'll consider it as an upgrading. The venture is always ahead of others, they are special."

"They are special; they are more competent than others." "They are not like any other sales venture, they are special. So competent." "Yea, this is a highly irregular activity." ... "There are no rules without exceptions."

"This is not a traditional contractual business; they provide new solutions." "We use to say no to such investments, regulation says no but they are innovative and see things that others don't." "Such actors are needed for showing best practice. Let's make an exception; we'll see big things happen in the future." 
Table 4: Defensive Postures

\section{Ignoring: Exemplary quotations}

"The final report is still not there; we'll wait and see if they notice anything. The damage will probably be higher for other actors and they may react." "Let's wait and see."

"This decision is against the rules." ..."We have agreed to it". "Moreover, we can't just change this decision since we don't know anything about it." "Let's do nothing for the moment."

"Further, our decision-making process is shorter and becomes more demanding. We can't require them to do everything right in accordance to regulations. So let's ignore this by now."

\section{Blaming External Others: Exemplary quotations}

"There is a lot of trouble with this person." "We are put on the wrong track, he has fooled us. He has not been open with his intentions to us." "We need to tell everyone that we have been fooled." "We took a wrong decision and don't want to be discredited for this."

"This decision doesn't follow the rules but that's not our fault." "We don't even know why the decision was taken." "The decision was taken by a former colleague and he had to back down even though he didn't like the decision." "So, he did not have the choice either as far as we know."

"There are also entrepreneurs who turn to influential people in top-management [of the government department]. They sneak in and then they come to us. Then everything is all set; the decision is taken. Then there is nothing we can do other than expedite the decision." "This was not an ideal situation and we were forced to just swallow the bitter pill and say yes. They had us to promote the investment. It was not our decision; it was not fully in accordance with regulation."

\section{Making Amends: Exemplary quotations}

"This situation is not the best; we stretched the rules a bit too far and need to make sure that it won't happen in the future. We'll just agree to follow the rules in the future." "It might be a bit tricky to remember but we'll surely do so."

"This is only an exception from the rule so we'll make it right next time. It will probably not be difficult since this was an extreme case." "Yea, we'll do that."

"I feel a bit that this was not the right decision; they do not stand up to the restrictions. Maybe we should have sent them to an adviser instead." "We can do that next time instead". "Let's go for this decision now."

\section{Confessing and Seeking Forgiveness: Exemplary quotations}

"This financing went slightly in the wrong direction." "We did an ugly thing since we believed in the idea. So we did what we did, absolutely not what we should do. Yea, we rather ask for forgiveness than for permission."

"We'll tell top management so they are prepared if something happens. We might need future support for this decision, a bit out of scope." "We need a higher degree of freedom in our decisions to be able to make the best decisions. Regulations restrict us too much so we occasionally need to ask for forgiveness as in this case."

"If media confronts us, it's only to confess that we made a big mistake financing this investment." "X you can take care of all contacts with media. You know the situation well and are competent to answer tricky questions that may arise."

\section{Correcting: Exemplary quotations}

"Based on these experiences it might be important for us to consider how to formulate future decisions. We can for instance write down a prerequisite in future contracts." "We do not contribute to overinvestment". "It is then easier for us to follow up and assure that we do the right thing when there is a written statement."

"We would like to work more on following up and evaluating decisions to enable development of a quality system-thinking. Evaluations regularly, feedback, impact, new prioritizing and policies. These are needs that we not have been able to fulfill that would certify that we don't stretch the rules."

"Still, if we keep this decision, we can guide the forthcoming applications in the right direction from the very beginning." "Absolutely, then we get rid of this problem." 